Article

\title{
Ptolemaic Cavalrymen on Painted Alexandrian Funerary Monuments
}

\author{
Sara E. Cole \\ Antiquities Department, J. Paul Getty Museum, Los Angeles, CA 90049, USA; SCole@getty.edu
}

Received: 12 March 2019; Accepted: 23 April 2019; Published: 28 April 2019

\begin{abstract}
The multiethnic environment of Ptolemaic Alexandria resulted in cross-cultural transmission of funerary practices and associated material culture that introduced many traditions to Egypt from the Mediterranean world. Along with an influx of mercenaries serving in the Ptolemaic army came cultural and artistic knowledge from their places of origin, which they (or their families) incorporated into their burials. One motif, which appears on late 4 th-3rd-century painted funerary monuments from Alexandria, is that of a soldier on horseback, alluding to images of the heroic hunter or warrior on horseback found in tombs in the regions of northern Greece. These Alexandrian monuments commemorated members of the Ptolemaic cavalry, some of whom are identified as Macedonian or Thessalian by accompanying Greek inscriptions. The image of a soldier astride his rearing horse not only emphasized the deceased's military status, but also established a link with Macedonian and Ptolemaic royal iconography. This type of self-representation served a number of purposes: to signal the deceased's cultural and geographic origins, demonstrate his elite role in Ptolemaic society and imply connections to the Ptolemaic court, all of which were important to the immigrant inhabitants of early Alexandria as they sought to express their identity in a new geographical, cultural, and political setting.
\end{abstract}

Keywords: Egypt; Ptolemaic; Alexandria; funerary

\section{Introduction}

A group of limestone funerary monuments from early Ptolemaic Alexandria bear painted images in Greek style of soldiers on horseback or horses being controlled by attendants. To my knowledge, these paintings have never been treated as a cohesive group though they share very similar iconography and styles drawn from the northern Greek mode of depicting heroic hunters and warriors on horseback. The monuments commemorated Macedonian and Thessalian members of the Ptolemaic cavalry. ${ }^{1}$ Their archaeological contexts, painting themes and styles, and the nature of their inscriptions all help date these objects to the late 4th-early 3rd century B.C. As some of the first inhabitants of Alexandria, these men had a range of choices - both local and imported from their homelands-in the mortuary practices and artistic styles they chose to employ. One's burial was a particularly meaningful context in which to express a deliberately crafted image of oneself, and the monuments that accompanied these individuals' burials speak to the aspects of their identity that they wished to communicate most fully both in death and in perpetuity on earth. ${ }^{2}$ That these men elected to emphasize their military roles, and to do so through the medium of Greek painting, speaks to the strong connection they wished to maintain with their places of origin as well as to the notion of elite status and heroism that they sought to elicit from viewers.

1 For an overview of the Ptolemaic cavalry, see (Fischer-Bovet 2014, pp. 125-33).

2 See (Venit 2009) on the use of "bilingual visual vocabulary" and theatricality related to funerary rituals in Alexandrian tombs. 
The objects presented here fall into three categories: loculus slabs, free-standing stelae, and one example of a painted frieze. All were found in Alexandrian tombs. While Alexandrian tombs drew upon Egyptian and Macedonian influences in their architecture and architectural decoration, their overall form was unique to Alexandria. The tombs ranged from simple rock-cut pits to underground hypogea, which could be intended for a single burial or could be much more elaborate, multi-chambered structures with central courtyards surrounded by burial chambers with numerous loculi cut into the walls to receive cremated, inhumed, or mummified remains. ${ }^{3}$ The individual loculi were sealed with painted limestone slabs, while free-standing stelae could be placed above-ground to mark burials. Both the slabs and stelae could have architectural framing in the form of a triangular pediment with acroteria, similar to that seen on funerary stelae elsewhere in the Hellenistic world. ${ }^{4}$ The painted frieze is reminiscent of similar paintings used to frame the entrances to elite Macedonian tombs, though in this case the painting appears on the wall of the interior courtyard of a large hypogeum, as this type of Alexandrian tomb did not have a monumental entrance but was instead accessed by a rock-cut staircase.

These five monuments are the only extant funerary paintings of cavalrymen in Alexandria of which I am aware, though it is possible that there are examples I have not encountered. It is important to note that three of the objects discussed here are in the collection of the Graeco-Roman Museum in Alexandria, Egypt, which has been closed for renovation since 2005. Its collections are inaccessible in storage and I have therefore not had the opportunity to view these objects in person. I have obtained images thanks to the generosity of colleagues, but professional photography has not always been possible. Only black and white photography is available for one: the fragmentary stela dedicated to Nikanor does not have an inventory number and so has been especially difficult for scholars to locate. These circumstances have necessarily limited the parameters of this analysis, as there are undoubtedly details visible to the eye that do not appear clearly in the photographs. Additionally, the paint has evidently faded over time in some instances, making the specifics of the iconography somewhat difficult to parse and resulting in details described in the objects' original publications that are no longer distinguishable. An in-depth examination of these monuments by a conservator would add valuable knowledge of the painting techniques and pigments used. The overall compositions, however, are comprehensible in the available photographs. Here, I present an overview of the five monuments, followed by northern Greek comparanda, and some hypotheses about the transmission of the rider on horseback motif and its significance for those who employed it in the context of burials in early Ptolemaic Alexandria.

\section{Catalogue of Painted Alexandrian Funerary Monuments Featuring Ptolemaic Cavalrymen}

1. Painted Limestone Funerary Slab with a Man Controlling a Rearing Horse (Figure 1),

New York, Metropolitan Museum of Art, Gift of Darius Ogden Mills, 1904, 04.17.3,

2nd half of the 3rd century BC,

$151 / 2$ in $\times 101 / 2$ in $\times 27 / 8$ in $(39.4 \mathrm{~cm} \times 26.7 \mathrm{~cm} \times 7.3 \mathrm{~cm})$,

Loculus slab.

Findspot: Found in 1884 in a tomb near Alexandria. The slab was gifted to the Metropolitan Museum in 1904 by Darius Ogden Mills along with five other painted stelae said to have come from the same tomb.

In 1885, Augustus Merriam reported the discovery of a rock-cut chamber tomb one year previously, measuring about $12 \times 14$ feet square, near the coast roughly a mile east of Alexandria (Merriam 1885, p. 18). The tomb contained around 50 vases, some of which were inscribed, as well as several painted "tablets" with poorly preserved images and, in some instances, Greek inscriptions. Elbert E. Farman,

3 On Alexandrian tombs, see (Venit 2002, 2016; Empereur and Nenna 2001, 2003).

4 For Hellenistic funerary stelae, see, e.g., (Fabricius 1999; Fraser 1977; Pfuhl and Möbius 1977-1979). 
former American Consul-General in Egypt, brought several of the finds from the tomb to the United States (Cook 1966, p. 16; Merriam 1887, p. 262). Among these objects were the six painted "tablets", which Farman loaned to the Metropolitan Museum of Art. There were evidently other painted stelae found "disposed about the wall of the tomb, but their condition was so bad that it was thought not worth while to transport them hither" (Merriam 1887, p. 262). The stelae all appear to belong to mercenaries and members of their families. Darius Ogden Mills purchased the slabs from Farman and later gifted them to the museum.

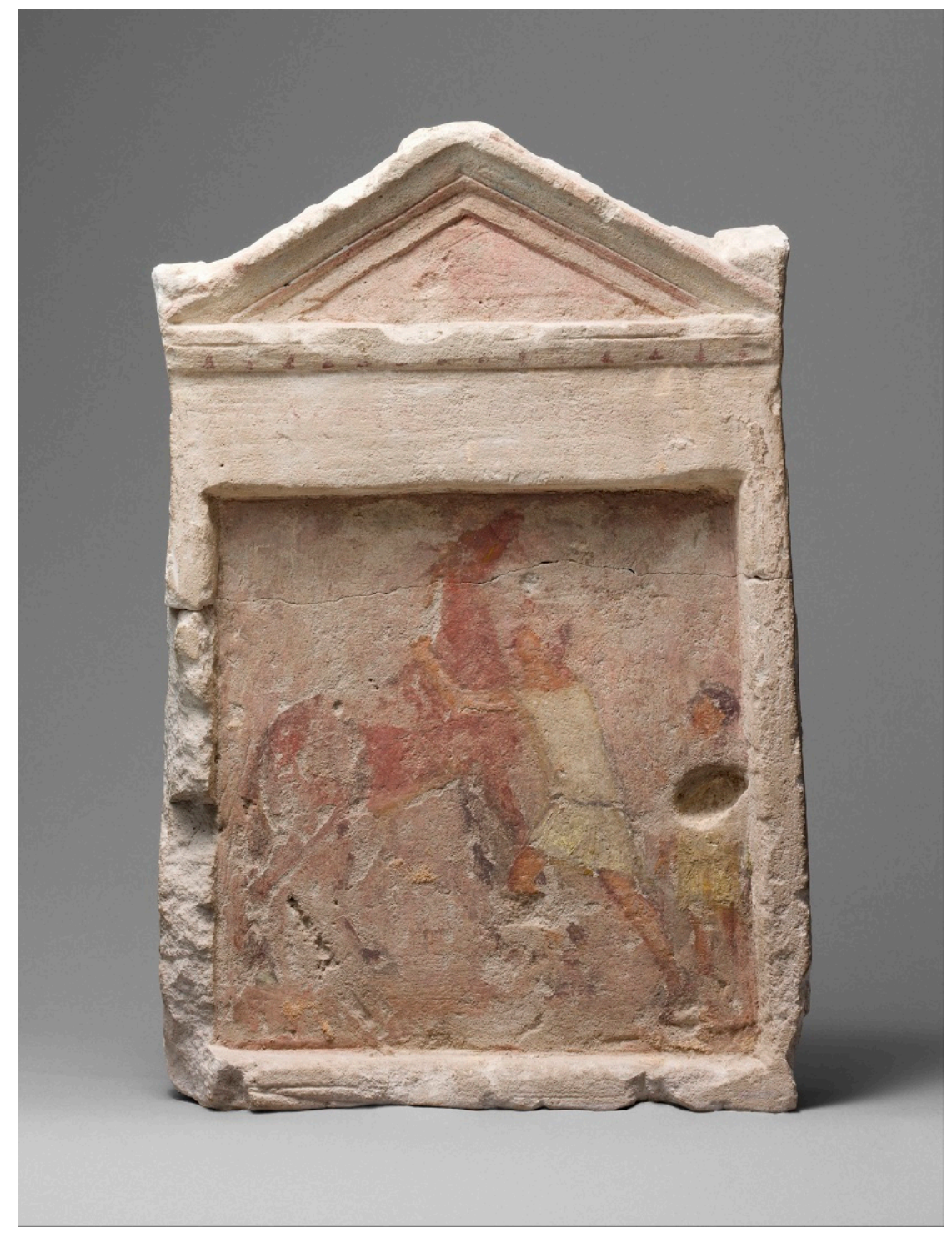

Figure 1. Painted Limestone Funerary Slab with a Man Controlling a Rearing Horse. (C) The Metropolitan Museum of Art.

Reinach (1888) believed that the six slabs came from the so-called Soldier's Tomb in the Ibrahimiya cemetery located near the coast to the east of the city. This tomb had been found in 1885 by Dr. Néroutsos-Bey, and contained vases and painted loculus slabs (Néroutsos-Bey 1887). Blanche R. Brown followed the identification of the tomb reported by Merriam and the one found by Néroutsos-Bey as identical (Brown 1957, pp. 16, 20, no. 4, pl. 5; followed by Abbe 2007), but this assumption has since been questioned (Miller 2014, p. 134, note 168; Cook 1966, pp. 15-18). Pagenstecher (1919, p. 54) listed Hadra as the findspot for this stela-it is unclear why. Richter (1927, p. 192); and again (Richter 1953, p. 132) recorded that the six stelae were found in the Hadra cemetery in the southeast 
area of the city, which others also repeated (Launey 1949-1950, pp. I, 513; Rostovtzeff 1941, p. 288). Given the description of the location of the tomb found in 1884, it seems that it was located in the Ibrahimiya cemetery, but it and the Soldiers' Tomb are likely two separate tombs from the same cemetery and same time period, both used by foreign mercenaries and their families. ${ }^{5}$

Inscription: "Pelopides, a Thessalian". The painted inscription is located beneath the architrave and runs horizontally; it is mostly worn away, but traces are still visible to the naked eye. It was suggested, prior to the publication of the inscription, that the stela belonged to a Galatian (Richter 1953, p. 132; Launey 1949-1950, pp. I, 513; Swindler 1929, pp. 344-46; Richter 1927, p. 192; Reinach 1911, p. 56), and indeed, three of the six stelae from this group are inscribed for Galatians. ${ }^{6}$

Painted Scene: Against a pink background, a young man in a short, pale yellow chiton attempts to bridle a rearing chestnut horse. The boy has reddish-brown hair on top of which he wears a conical hat. A second young man, also in a yellow chiton but with dark brown/black hair and no cap, stands to the far right and looks on. The image captures a strong impression of liveliness and energetic motion-the horse strains its neck upward, raising its front legs off the ground, as the boy lunges forward to grasp the animal with both arms. Although Pelopides is not himself pictured, he is present through the inscription and presumably the two boys pictured are his attendants who have been tasked with bridling his horse. The composition may thus refer to preparations for battle or training.

The same painting technique was used for this and the other five stelae with which it was found. The surface of the stone was smoothed down and a layer of lead white was added on the area to be painted: "The recessed picture panel of each was prepared with a lead white ground to create a flat, uniform, and brilliant white surface, a preparation technique undoubtedly transferred from contemporary wooden panel painting. An outline of the composition was incised in this ground layer and then delineated with extensive preparatory drawing using carbon black. The painting process involved building subtle color values and tones through overlapping applications of both pure colors and subtle mixtures of colors to maximum effect" (Abbe 2007).

Select Bibliography: (Plantzos 2018, pp. 259-61, Figure 253; Miller 2014, pp. 205-7, Figure 5.23; Picón 2007, pp. 186, 447, no. 213; Cook 1966, pp. 12, 16-18; Brown 1957, pp. 16, 20, pl. V; Richter 1953, pp. 132-33; Launey 1949-1950, pp. I, 513; Rostovtzeff 1941, pp. 288-9, pl. XXXVII.2; Swindler 1929, pp. 344-46, Figure 551; Richter 1927, p. 192; Pagenstecher 1919, p. 54, no. 54, 69; (Reinach 1911, p. 57, no. 10 (under no. 2154), Figure 9); Merriam 1887, no. IV, p. 265; Merriam 1885, p. 18).

2. Funerary Stela of a Man on Horseback (Figures 2-4),

Alexandria, Graeco-Roman Museum, 22116,

3rd century BC,

$35 \mathrm{~cm} \times 25 \mathrm{~cm}$.

Free-standing stela (after Brown 1957, p. 25). The top of this stela is broken away; it does not have a sunken panel.

5 I erroneously stated that the slab came from the Soldiers' Tomb (Cole 2019, p. 88).

6 Metropolitan Museum of Art 04.17.4 and 04.17.6: (Casagrande-Kim 2014, p. 104, cat. 121 and 122); Metropolitan Museum of Art 04.17.5: (Plantzos 2018, pp. 259-61, Figure 251). 


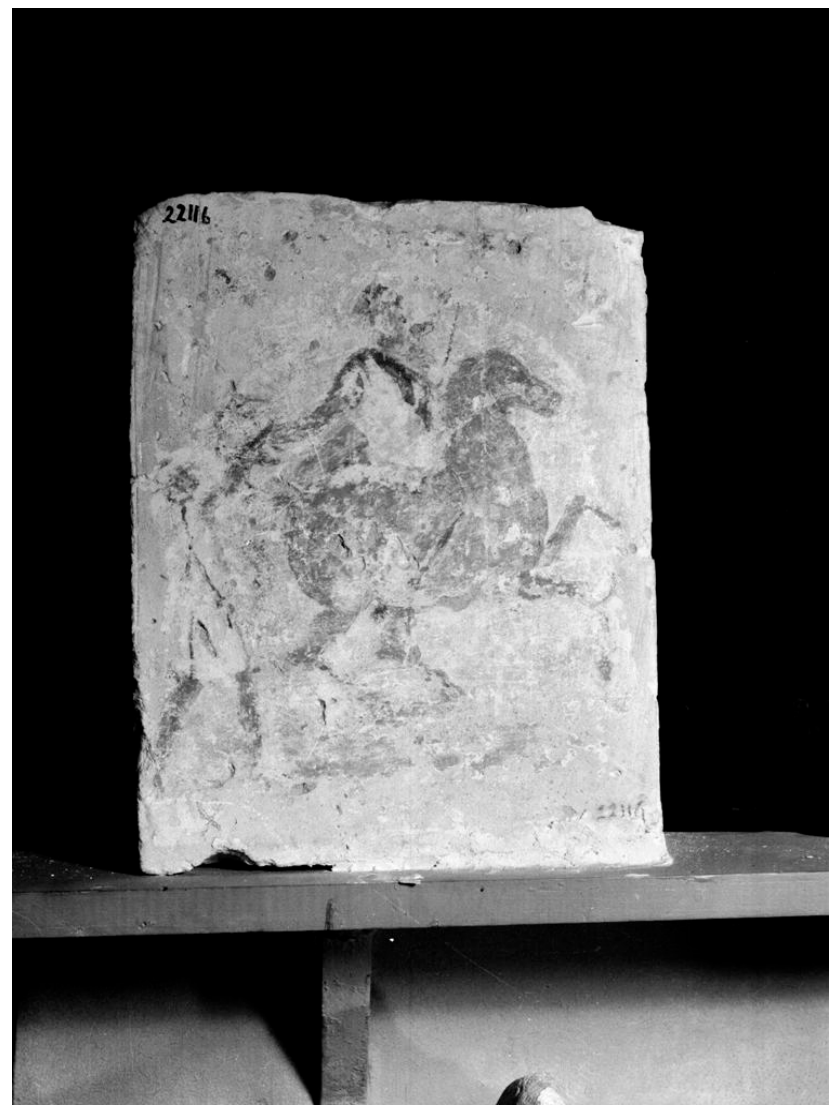

Figure 2. Funerary Stela of a Man on Horseback. Photograph courtesy of Kyriakos Savvopoulos.

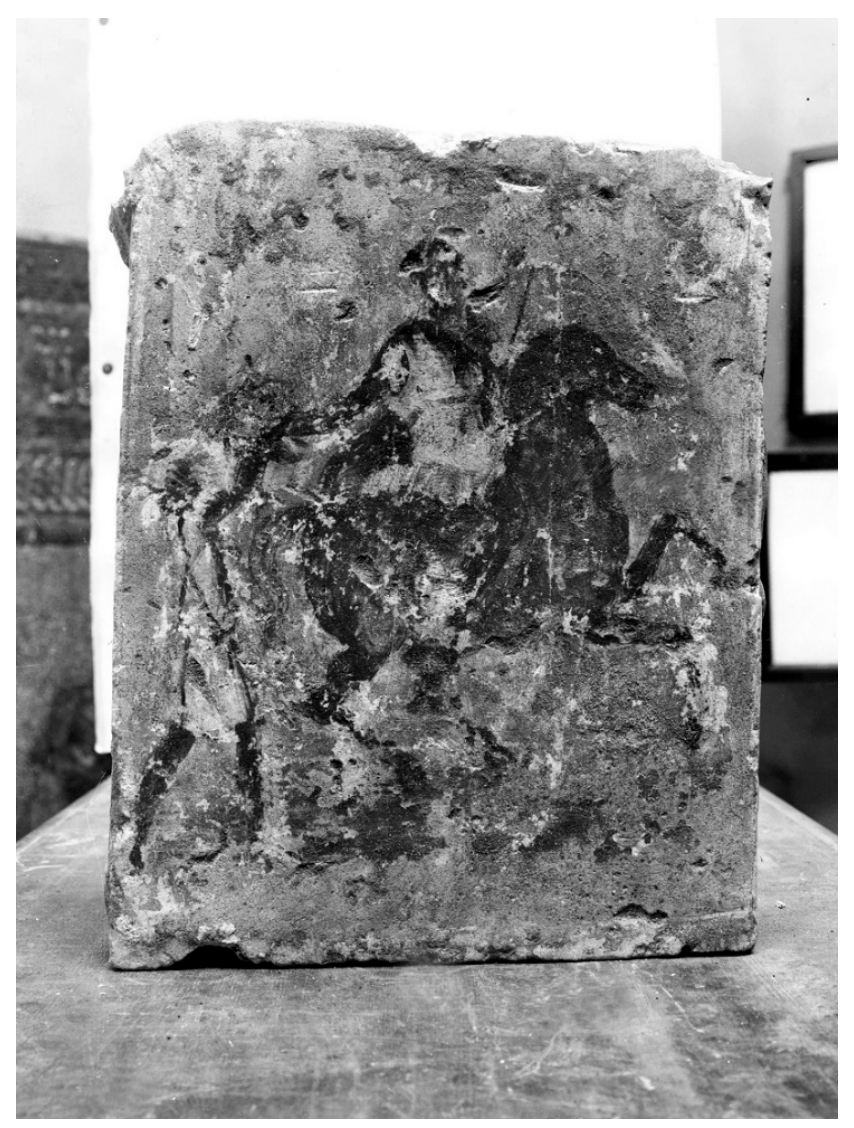

Figure 3. Funerary Stela of a Man on Horseback. Photograph courtesy of Kyriakos Savvopoulos. 


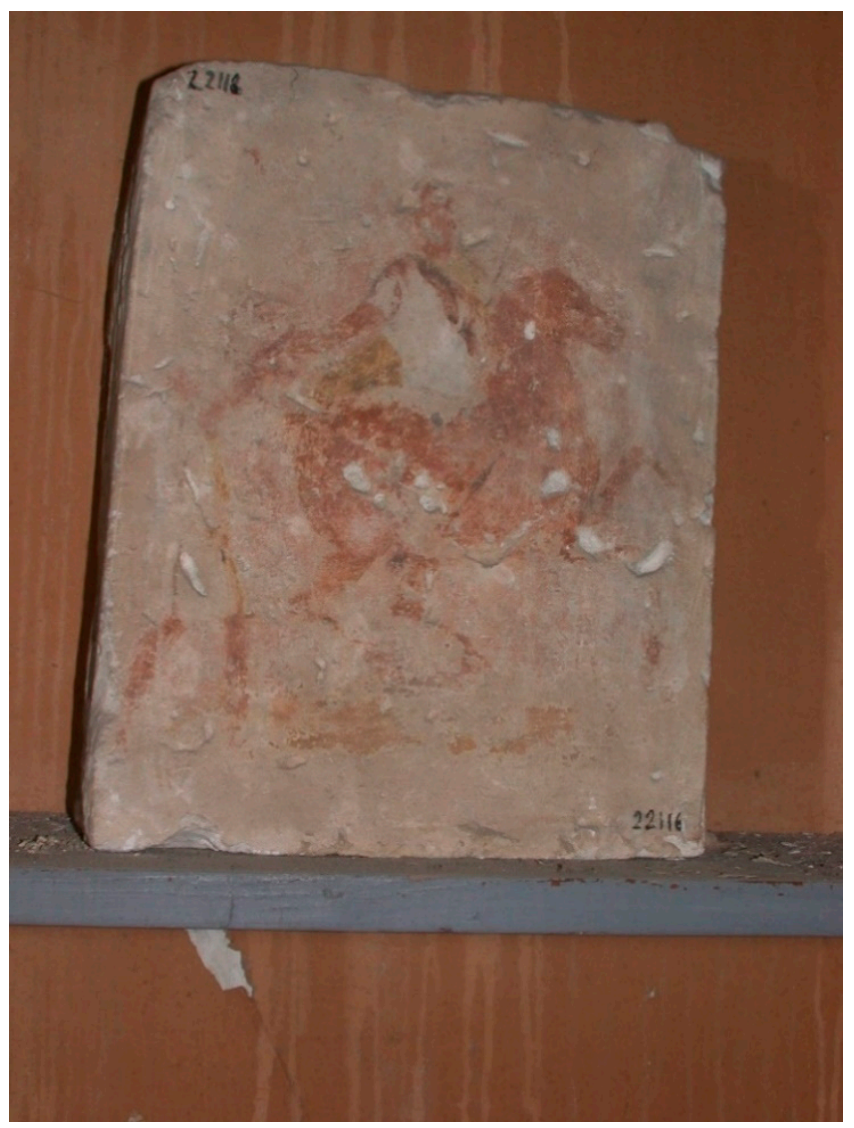

Figure 4. Funerary Stela of a Man on Horseback. (C) Centre d'Études Alexandrines.

Findspot: Discovered by Evaristo Breccia in 1925-1926 in the Hadra cemetery, Alexandria, in surface accumulation (Breccia 1930, p. 106).

Inscription: This stela has no preserved inscription.

Painted Scene: A soldier is mounted on a chestnut horse against a pink background. The horse rears to the right as the soldier turns back to a young man at left who wears a pale yellow belted chiton and holds the man's helmet out to him. The soldier is wearing a pale yellow belted tunic, blue cuirass, and reddish chlamys (cloak), and has a spear in his left hand. His hat is somewhat difficult to determine, but it appears similar to the Macedonian kausia.

Select Bibliography: (Brown 1957, pp. 24-25, no. 16, pl. X; Breccia 1930, pp. 106, 116 pl. XII).

3. Funerary Stela of a Soldier on Horseback (Figures 5 and 6),

Late 4th-3rd century BC,

Alexandria, Graeco-Roman Museum, 10228,

$40 \mathrm{~cm} \times 37 \mathrm{~cm}$,

Free-standing stela without a sunken panel (after Brown 1957, p. 26). 


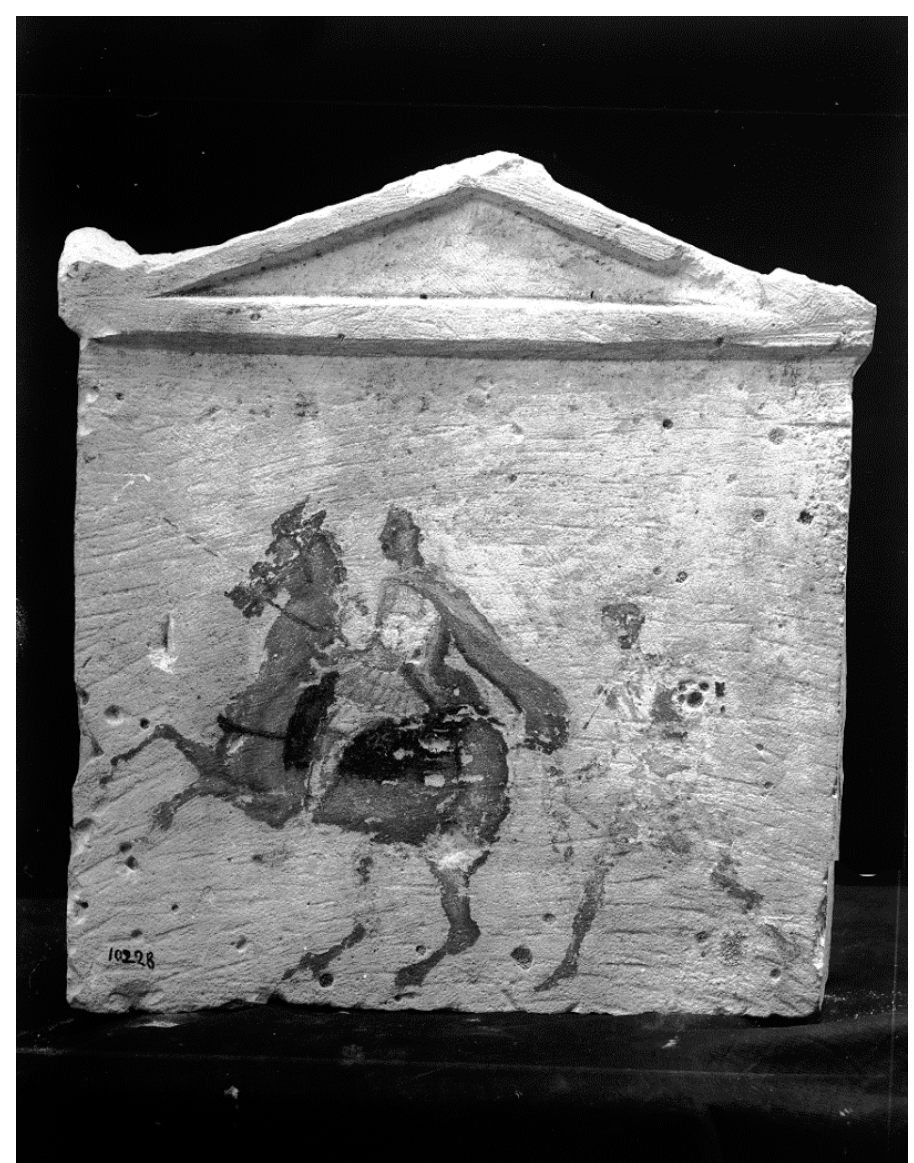

Figure 5. Funerary Stela of a Soldier on Horseback. Photograph courtesy of Kyriakos Savvopoulos.

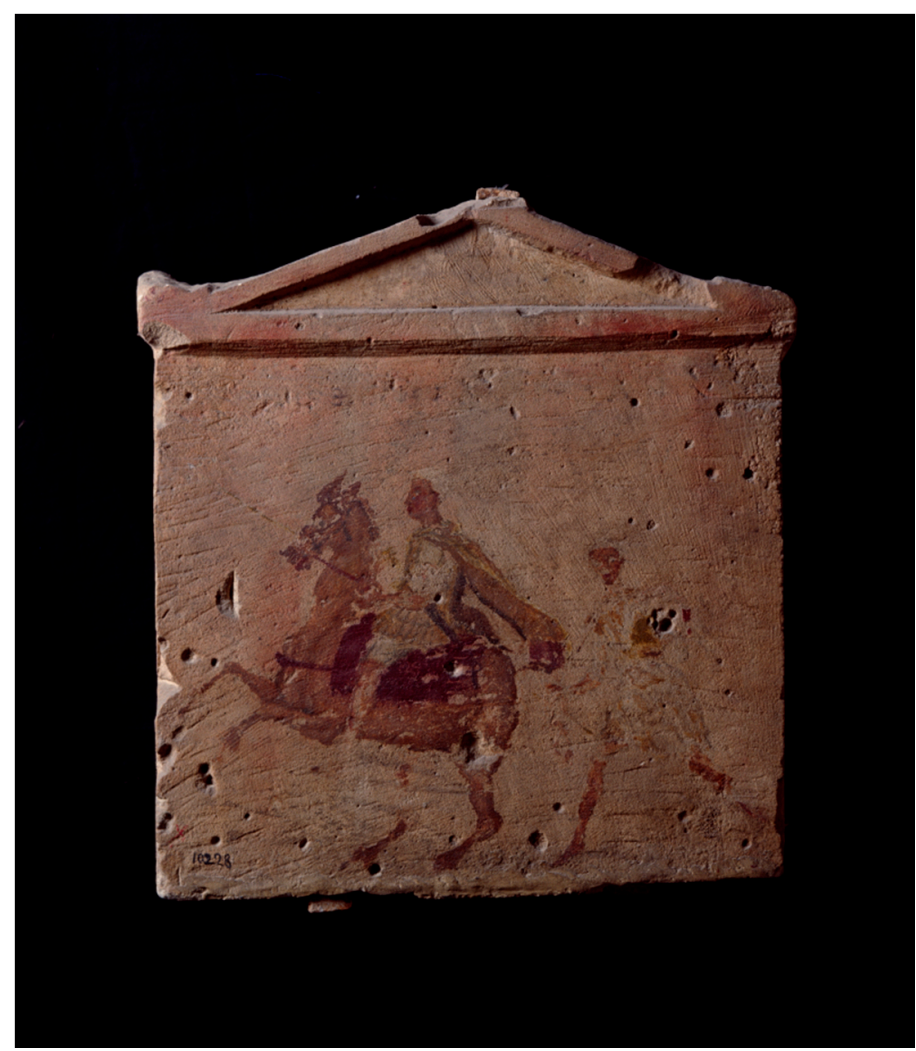

Figure 6. Funerary Stela of a Soldier on Horseback. (C) Centre d'Études Alexandrines. 
Findspot: Found in 1904 in the Shatby necropolis in surface accumulation. Shatby is the earliest known cemetery in Alexandria and was excavated by Evaristo Breccia $(1912,1905)$.

Inscription: “ . . xenos, a Macedonian” (Launey 1949-1950, pp. II, 1186; Breccia 1912, vol. 1, pp. 10-11, no. 9, vol. 2: pl. XXII-XXIII). The inscription is painted horizontally beneath the architrave. As with the Metropolitan Museum of Art slab (no. 1 above), this stela was previously thought to belong to a Galatian (Reinach 1911, pp. 57-58, no. 11, Figure 10).

Painted Scene: Against a red-pink background, a soldier sits astride his chestnut horse as it rears to the left. The horse is outfitted with a bridle and a dark purple saddle cloth and saddle. The soldier wears a greenish-yellow chiton and pale yellow cuirass with a skirt made of leather thongs. He holds the horse's reigns with his left hand and carries a long Macedonian spear (sarissa) with his right. A sword is strapped to his belt, but he evidently wears no helmet. A long saffron-yellow chlamys with purple border billows behind him. Breccia (1912, p. 10) noted the similarity of this costume to that worn by Alexander the Great in the Alexander Mosaic. A young man in a pale yellow chiton runs behind the horse, holding the animal's tail with his right hand as he turns his face out to the viewer.

Select Bibliography: (Plantzos 2018, pp. 259-60, Figure 252; Fischer-Bovet 2014, p. 130 Figure 4.4; Hassan 2002, pp. 136-37; Brown 1957, p. 26, no. 21 pl. XI; Rostovtzeff 1941, pp. 150-51, pl. XIX.1; Pagenstecher 1919, p. 54, no. 53; Breccia 1912, vol. 1, pp. 10-11, no. 9, vol. 2: pl. XXII-XXIII; Reinach 1911, pp. 57-58, no. 11, Figure 10; Breccia 1905, pp. 78-80).

4. Funerary Stela of Nikanor, a Macedonian (Figure 7),

Alexandria, Graeco-Roman Museum,

$44 \mathrm{~cm} \times 44 \mathrm{~cm}$,

3rd century BC,

Free-standing stela (after Brown 1957, p. 28).

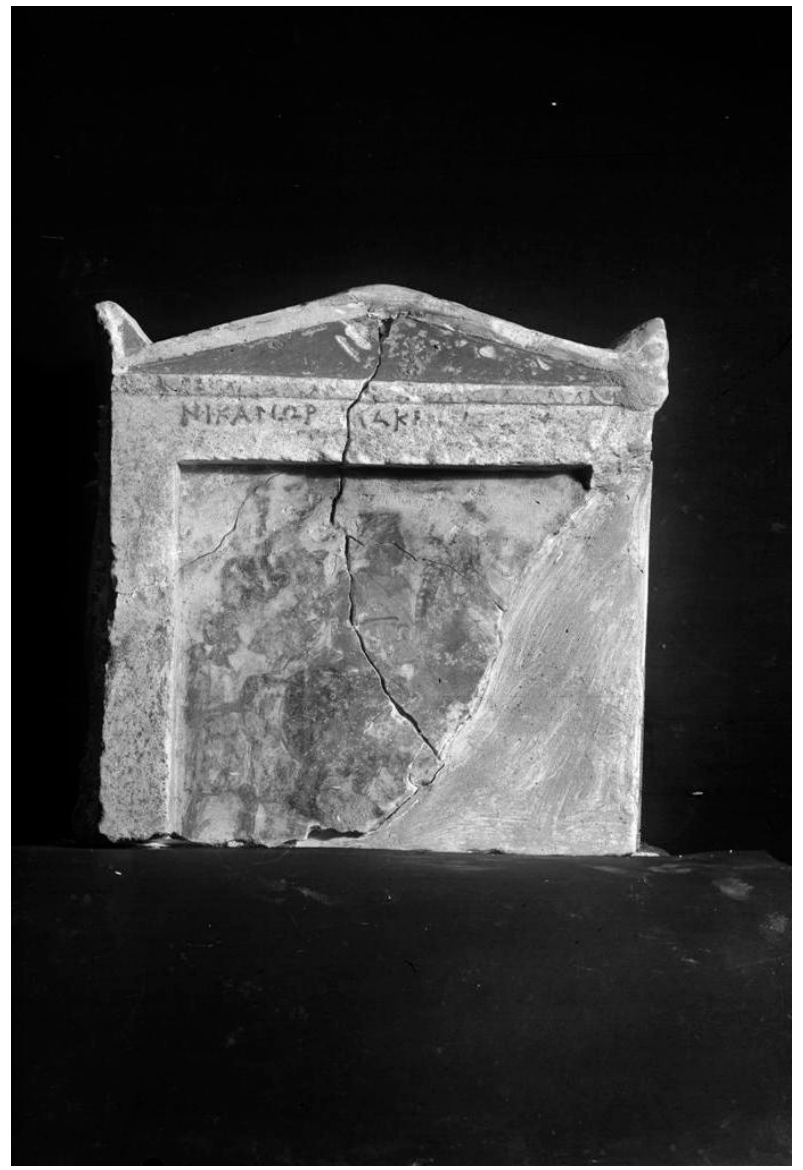

Figure 7. Funerary Stela of Nikanor, a Macedonian. Photograph courtesy of Kyriakos Savvopoulos. 
Findspot: Found in 1940 in the Hadra necropolis, in the area of the cemetery of al-Manara (Adriani 1952, pp. 25-27, Figure 18, Pl. VIII, I).

Inscription: "Nikanor, a Macedonian" (Adriani 1952, p. 27). The inscription is painted horizontally beneath the architrave.

Painted Scene: While a large portion of this stela is now missing, the majority of the painted scene is visible, though very weathered. For the most part, only the brown underpainting remains. A soldier wearing a conical helmet, belted chiton, and violet (?) ${ }^{7}$ chlamys rides his horse to the right. He is followed by a young man in a yellow belted chiton who holds the horse's tail, similar to the attendant on the stela from the Shatby necropolis.

Select Bibliography: (Brown 1957, p. 28, no. 26, Pl. XIX, I, 2; Adriani 1952, pp. 25-27, Figure 18, Pl. VIII, I).

5. Painted Frieze (Figures 8 and 9),

Alexandria, Moustapha Kamel Tomb I,

Mid-3rd century BC,

$167 \mathrm{~cm} \times 60 \mathrm{~cm}$.

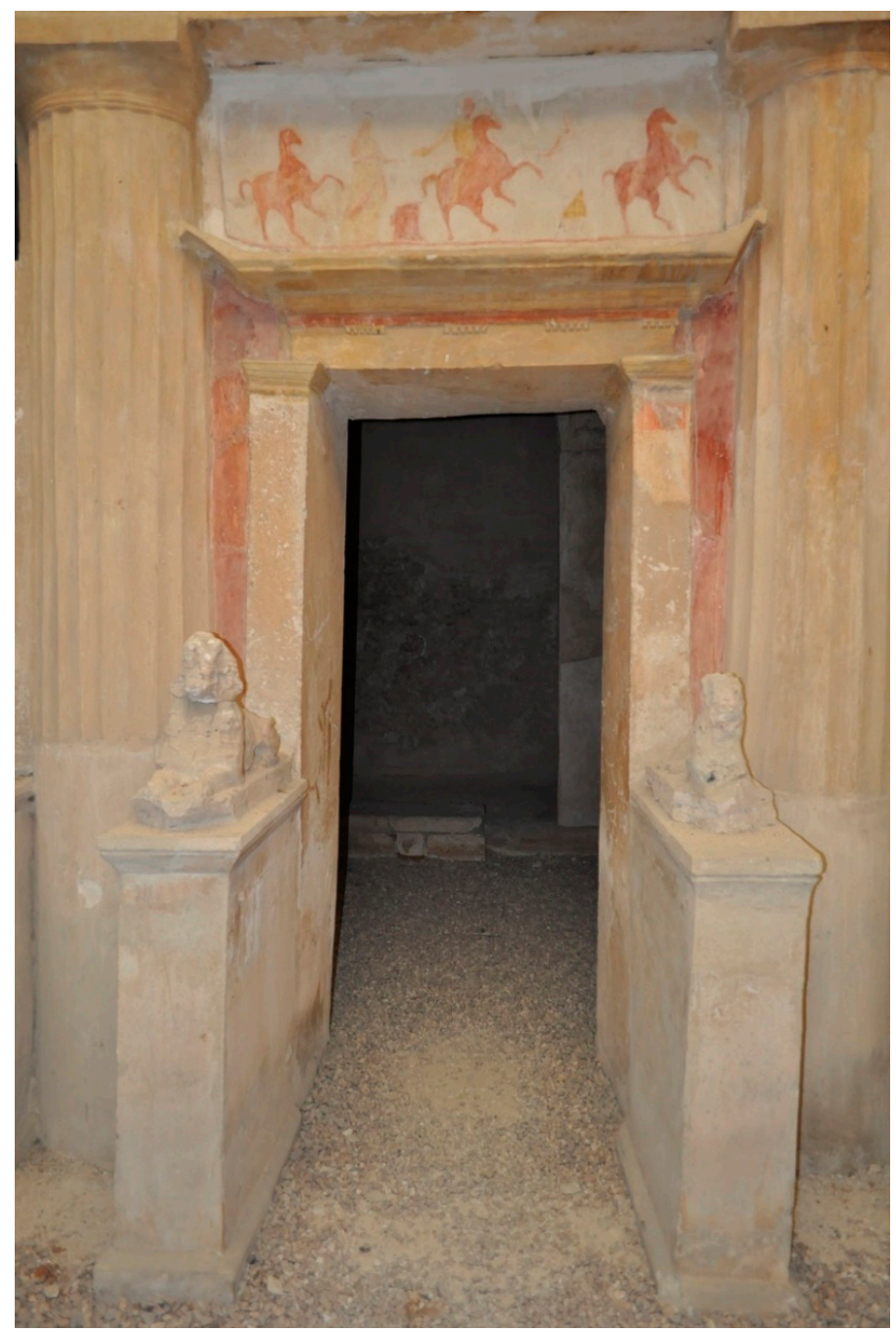

Figure 8. View of the central doorway in the south wall of the courtyard, Moustapha Kamel Tomb I, Alexandria. Photograph courtesy of Kyriakos Savvopoulos. 


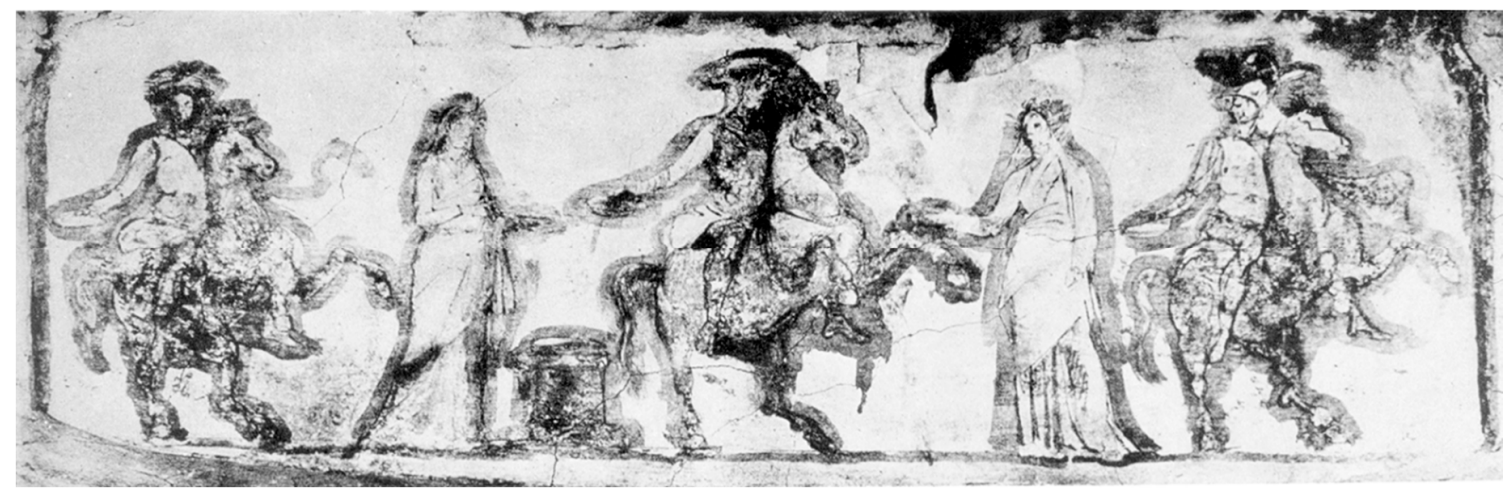

Figure 9. Moustapha Kamel Tomb I painted frieze. After (Venit 2002, p. 57, Figure 42).

Findspot: This painted frieze remains in situ on the south wall of the courtyard in Moustapha Kamel (formerly Moustapha Pasha) Tomb I. This cemetery is located to the east of the city and was excavated by Achille Adriani in the 1930s (Adriani 1936, pp. 15-44).

Inscription: The frieze has no inscription.

Painted Scene: The frieze was painted over the central of three doorways on the south wall of the tomb's courtyard, which formed a Doric peristyle. This doorway led into the kline chamber, where the body of the deceased would have been laid out, so that the scene bears a direct relation to the individual interred within (the tomb also contains numerous loculi for additional burials). Much of the pigment has faded, but the original dark brown underpainting is discernable. In this scene, three men in Macedonian military attire sit astride rearing horses. The central rider is flanked by two standing women who turn toward him. The riders each wear a chiton, cuirass, and chlamys, and each has a sword at his belt. The rider at the right has a Macedonian helmet with cheek-pieces and a crest and, on his feet, he wears either boots (krepides) or high-laced sandals. The central and left riders wear a kausia. The two women each wear a long chiton with a himation belted at the waist and veiled over their heads.

An altar stands just left of center and each figure bears a phialai (shallow offering dish) in order to pour libations; the riders all extend their phialai in their right hands. The scene may perform double duty by suggesting a military role for the primary occupant of the tomb (whose identity is unknown) and mirroring the funeral rituals that took place within the tomb (Miller 2014, p. 188; Cole 2019, pp. 87-88), where an altar at the center of the courtyard still contained ashes from the funerary rites (Adriani 1936, p. 19). The tomb's open courtyard would have been used not only at the time of the funeral but repeatedly over time as additional burials took place in the tomb's loculi and as family members returned to perform the ongoing funerary cult. Moustapha Kamel Tomb I contained an elaborate well system-gathering and pouring water must have been among the most significant rituals performed. Mourners could also have poured libations and burned sacrifices at the altar. The frieze's position in the courtyard made it visible to those performing these activities and to individuals who looked into the space from above.

While much of the pigment is now lost, the colors of the frieze were more visible at the time of excavation and were noted by Adriani (1936, pp. 110-11); see also (Venit 2002, p. 56). The underpainting was executed in fresco technique, in which a layer of stucco was applied to the stone surface and was painted on while still wet. The other colors were then layered on top of this underpainting. The background of the scene was painted blue. The cavalrymen ride chestnut horses and have reddish skin. The right rider wears a purple chiton and yellow chlamys. The central rider wears a yellow cuirass. The left rider wears a yellow kausia, blue cuirass, and yellow chiton. The altar is painted red and each of the phialai is yellow to indicate bronze or gold. The women had slightly lighter skin tones than the men, and the woman at the right of the central rider wore a red chiton.

None of the figures are identified by inscription but it is possible, given that in similar scenes from northern Greek tombs, the deceased is typically represented in such a context, that one of the riders 
(perhaps the central one) is the deceased. The other individuals depicted might be his family members, commemorating him through ritual libation. That all of the men are mounted soldiers could signal that this was an elite family with a hereditary tradition of serving in the cavalry.

Select Bibliography: (Cole 2019, pp. 85-89, Figure 4.2; Plantzos 2018, pp. 250-51, Figures 238-40; Venit 2002, pp. 55-58, Figure 42; Miller 2014, p. 188, Figure 5.10; Brown 1957, p. 84, pl. XXIV.1; Adriani 1936).

All five scenes show the same relatively limited color palette of red/pink, brown, yellow, purple, and sometimes blue, with dark brown underpainting. The manner of depicting the deceased on the slabs and stelae- - on a rearing horse followed by an attendant who either grabs the horse's tail or hands something to the rider-is the same across three of the four examples. The attire worn by the cavalrymen and their attendants is also consistent and includes elements of Macedonian attire: the kausia, chlamys, and krepides. ${ }^{8}$ In the stela of "... xenos, a Macedonian" and in the Moustapha Kamel frieze, the riders wear yellow cloaks, which were part of the typical attire of Ptolemaic cavalrymen, just as it had been for Alexander's companions (Fischer-Bovet 2014, p. 131). Others wear purple cloaks, a color associated with royalty in Macedonia.

The stela of Pelopides stands out as exceptional in that it does not depict the deceased but rather his horse and two attendants. Three of the four examples bear painted inscriptions beneath the architrave that provide the deceased's name and ethnic. The Moustapha Kamel frieze mirrors the type and placement of similar painted friezes that depicted the deceased over the entrances to Macedonian tombs (see, for instance, the Vergina example discussed below). In general, it appears that there was a fairly standardized way of representing and identifying Ptolemaic cavalrymen on painted funerary monuments in the early phase of the Ptolemaic dynasty.

\section{Northern Greek Comparanda}

Several funerary paintings depicting a heroic hunter or warrior on horseback come from eastern Mediterranean contexts, particularly chamber tombs in Macedonia and Thrace that predate or are contemporary with the Alexandrian funerary monuments. Themes of hunting and warfare were of course not exclusive to the Hellenistic period or to northern Greece, but I focus specifically on funerary monuments from this time and place as these are the likeliest source of direct inspiration for the traditions replicated in Alexandrian tombs. ${ }^{9}$

In Hellenistic tombs, the related pursuits of the hunt and the battle-emphatically elite male activities-were used to proclaim the kleos (fame, glory) and arête (valor, honor) of the deceased (Miller 2014, p. 174). In both Macedonia and Thrace, horsemanship was a sign of elite status. The Thracians were widely known for being skilled horsemen. ${ }^{10}$ In Thrace, such imagery had an additional association with the so-called Thracian Rider, a hunter on horseback who recurs on both votive and funerary stelae beginning in the Hellenistic period and who became widely popular in the Roman period. ${ }^{11}$ The Thracian Rider could be taken to represent a wide range of deities or the deceased himself depending on context: "the horseman is an iconographical convention for a god or hero, and the inscriptions serve to personalize (and identify) this otherwise nameless conventional image" (Dimitrova 2002, p. 217). When used in a funerary setting, the motif was closely associated with the

8 On these elements of Macedonian costume, see (Saatsoglou-Paliadeli 1993; Fredricksmeyer 1986).

9 Schmitt and Schnapp (1982) discuss the link between the hunt and the symposium in Archaic Greek vase painting, and Vermeule (1979) considers the poetic and artistic themes of hunt, war, and rape/abduction as they relate to death in the Greek imagination.

10 On the Thracian cavalry, see (Webber 2003).

11 A wide variety of interpretations of the identity and significance of the Thracian Rider have been put forward. See (Andrianou 2017, pp. 110-25) for an overview; and (Boteva 2011, p. 86, note 12) for relevant bibliography. See also LIMC VI.1. (1992), s.v. "Heros Equitans", 1019-1081 (A. Cermanović-Kuzmanović et al.). In addition to being shown as a hunter, the Thracian Rider also appears astride a walking horse approaching a snake-entwined tree. The votive and funerary stelae are so similar in their use of these two motifs that their function is often only ascertainable by their inscriptions. 
heroization of the deceased in Thracian funerary cult. ${ }^{12}$ The heroization of the dead has its origins in east Greece in the 6th century BC but only became widely used by the populace - not only in Thrace but throughout the Greek world-in the Hellenistic period (Hughes 1999). These themes of kleos, arête, and heroization were all entangled with one another; they became embodied by the hunter or warrior on horseback in northern Greek art and were subsequently transmitted to Alexandria. ${ }^{13}$

In Hellenistic funerary art, military associations were often referenced through the representation of shields and weaponry either alone or alongside depictions of the deceased, ${ }^{14}$ but images of men on horseback actively engaging in a hunt or battle also appear. Painted military and hunting themes in Hellenistic tombs have been summarized elsewhere, ${ }^{15}$ so I present here a limited selection of parallels drawn from the region that supplied the Ptolemaic cavalry in the early Hellenistic period (late 4th-3rd century BC): northern Greece, particularly Macedonia and Thrace. This list is not meant to be comprehensive but rather to examine a few funerary monuments that show close compositional and iconographic similarities and exemplify the ideological associations of the warrior on horseback that also manifest in the Alexandrian paintings.

Painted funerary stelae were in use throughout northern Greece during the Hellenistic period, ${ }^{16}$ and many of the scenes found on these monuments are repeated on painted Alexandrian monuments. Common motifs on Alexandrian stelae and loculus slabs were parting (dexiosis) scenes for both men and women, images of the deceased with family members in domestic settings, and soldiers standing at rest with their weapons. The rider images catalogued above form a relatively small group among the extant paintings. The closest parallels for the motif of the cavalryman on horseback come from carved relief stelae and painted friezes in monumental northern Greek tombs. A white marble stela from ancient Herakleia (Gephyra) in Macedonia provides a close precursor to the depiction of cavalrymen in Alexandrian funerary monuments and is slightly earlier in date. The stela dates to ca. 300 BC and is inscribed for a cavalryman named Nikanor, son of Herakleides. ${ }^{17}$ In the relief scene, set into a recessed panel, Nikanor is on horseback; his rearing horse advances to the right. His thick chlamys billows dramatically behind him and he wears a cuirass over a long-sleeved garment and possibly also tights (anaxyrides) in the Persian manner. This costume is similar to that worn by the cavalryman depicted in a tomb at Kerch (discussed below) (Hatzopoulos and Juhel 2009, pp. 428-29). Aspects of Persian costume were adopted by the Macedonian army after Alexander the Great's eastern campaigns. Nikanor's helmet is of the Attic type. A curved line may indicate the outline of a shield held in his left hand (Hatzopoulos and Juhel 2009, pp. 431-32). He is followed by a young male attendant draped in a heavy cloak, who stands just behind the horse's tail.

Numerous Macedonian funerary stelae with carved relief scenes from the 5 th-1st century BC include horsemen, sometimes accompanied by attendants or other figures. ${ }^{18}$ In general, on the

12 On the heroized dead as a warrior or hunter on horseback, see (Wypustek 2013, pp. 65-66).

13 It is worth noting that hunt and battle scenes appear frequently in Greek mosaics, a medium that was closely related to painting. Westgate (2011) examines this theme in mosaics as representative of Greek masculinity, particularly in Hellenistic Macedonia. Greek pebble mosaics were adopted in Alexandria: a stag hunt mosaic found in the palace quarter (McKenzie 2007, p. 68 Figure 98) resembles a stag hunt mosaic from the House of the Abduction of Hades in Pella (Franks 2012, p. 63, Figure 47; Cohen 2010, pl. I) and a lion hunt mosaic from the House of Dionysus at Pella (Franks 2012, p. 62, Figure 46; Cohen 2010, p. 67, Figure 21, pl. IV). In a partially preserved Alexandrian mosaic, a nude warrior brandishes a spear and shield (Cohen 2010, pp. 133-34, Figure 61).

14 Warriors with their weapons also appear on painted Alexandrian funerary monuments, but the present discussion is focused specifically on the mounted rider motif. Isolated weapons, without human figures, appear on early Hellenistic painted stelae from the Tower of Zeno in the Chersonese, for which, see (Posamentir 2011). The painted lunettes in the burial chamber of the Tomb of Lyson and Kallikles at Lefkadia depict military gear but do not include images of the deceased individuals: see (Miller 1993). The so-called Ghirghis tomb at Alexandria includes a kline chamber in which an Egyptian naiskos is carved in relief, surrounded by relief images of Greek arms and armor; the deceased evidently adhered to Egyptian funerary religion but also wished to signal his elite status as a member of the Ptolemaic military: see (Venit 2002, pp. 92-93, Figure 76).

15 For a summary of painted military and hunting imagery in Hellenistic tombs, see (Miller 2014, pp. 185-97).

16 See examples in (Kalaitzi 2016; Posamentir 2011; Brecoulaki 2006; Rouveret 2004; Arvanitopoulos 1928).

17 (Hatzopoulos and Juhel 2009, cat. 4, Figures 8-10). Kilkis Archaeological Museum, inv. no. 2315.

18 See examples in (Kalaitzi 2016). 
Macedonian stelae the scenes are set into recessed panels in which riders advance to the right, sometimes toward another figure, and are followed by an attendant. They wear a chiton, chlamys, and sometimes krepides. In some instances, they carry arms. On the stela of Philippos from Kolindros the rider carries a phiale in his right hand (Kalaitzi 2016, pp. 178-79, no. 31), similar to the riders in the Moustapha Kamel frieze. Several of the Thracian Rider stelae also show the horse rearing upwards, followed by a male attendant who sometimes holds the horse's tail. ${ }^{19}$ Though specific aspects of the iconography differ, the overall composition of a single armed cavalryman with a billowing chlamys, astride a rearing horse, followed by an attendant, is directly adopted on the Alexandrian painted stelae and loculus slabs.

Other images of men on horseback appear in paintings in Macedonian and Thracian tombs. Perhaps the most well-known example is the hunt frieze from the so-called Tomb of Philip (Tomb II) at Vergina, Macedonia, which dates to the second half of the 4 th century BC. ${ }^{20}$ This frieze, located above the tomb's entrance, depicts ten hunters in various stages of dress as they pursue deer, a boar, a bear, and a lion in a wooded landscape (Miller 2014, pp. 192-94, Figure 5.14; Franks 2012; Brecoulaki 2006, pp. 103-33, pl. 27-43; Moreno 2004, pp. 123-32; Saatsoglou-Paliadeli 2004; Andronicos 1984, pp. 106-18). Three of the men are on horseback, the remainder are on foot. The composition is organized around the figure of a young rider at center. He wears a purple chiton and boots and is singled out by the wreath of leaves on his head. His horse rears to the right and he raises his spear to hurl it at a lion. A slain boar lies behind him. A bearded (and therefore more mature) horseman at the far right of the scene is engaged more closely with the lion, aiming his spear at the animal's head as it looks over its shoulder to growl at him. He is fully clothed, wearing a chiton and chlamys. This man is distinguished from the others by his beard, his position on horseback, and the fact that his rearing horse places the figure higher than any other in the scene. The central and right horsemen are believed by most to represent Alexander the Great and his father Philip II. ${ }^{21}$ Alexander was very fond of hunting and is recorded in ancient sources hunting both boars and lions. ${ }^{22}$ To the left of the central rider, situated between two trees, stands a tall column or pillar upon which stand several objects, perhaps statues. The exact nature of the monument is difficult to determine due to the painting's state of preservation. Cohen (2010, p. 258) suggests that this could represent a heroon. If this were the case, it would be direct evidence for the heroization of the dead king in Macedonian funerary cult. ${ }^{23}$

In Greece, the hunt could serve as a training ground in which to hone one's skills for battle, ${ }^{24}$ and in Macedonia it was also a leisure pursuit associated with royalty. Beginning with the reign of Philip II, adolescent sons of nobles accompanied the king on his hunting expeditions. ${ }^{25}$ Hunts could also serve as a rite of passage for elite men: Athenaeus reports that at the Macedonian court, men had to eat sitting upright until they had single-handedly killed a boar, at which time they were permitted to dine reclining. ${ }^{26}$ Hunting imagery was thus closely linked to military prowess as well as to masculinity and social status. One's skill at the hunt was intimately related to elite male identity in Macedonia. That in

19 (Andrianou 2017, pp. 123-24, 212, and 349, Relief 27, 213-14 and 352-55, Relief 29, 214-15 and 356-57, Relief 30). Note that these examples date to the late Hellenistic-early Roman period.

20 The tomb was discovered by Manolis Andronicos in 1977: see (Andronicos 1984). On the ongoing debate about the identity of the cremated man and woman buried within the tomb, who are thought to be either Philip II and his wife Kleopatra or Philip III Arrhidaios and Euridike, see (Hatzopoulos 2016).

21 E.g., (Hatzopoulos 2016, pp. 114-15; Saatsoglou-Paliadeli 2004, pp. 165-69; Andronicos 1984, pp. 115-17, 230). Tripodi (1998, pp. 106-9) argues that they are instead Alexander IV and Philip III Arrhidaos, while Baumer and Weber (1991, pp. 38-41), followed by Badian (1999, pp. 87-88), identify them as Philip III Arrhidaios and Philip II. Palagia (2000, pp. 195-97) suggests Philip Arrhidaos and Alexander.

22 Plutarch, Alex 40.4-5; Arrian, Anabasis 4.13.2; Curtius History of Alexander 8.1.13-17, 8.6.7.

23 Franks (2012) argues that the main subjects of the frieze intentionally align themselves with the heroes of Greece's mythic past as well as their own Macedonian dynastic ancestors.

24 Xenophon, Cynegeticus 1.18; 12.1-9. Strabo Geographica 10.4.21 also reports that on Crete, youths were prepared for battle by hunting.

25 Arrian, Anabasis 4.13.1. Arrian also reports that the Macedonian king hunted on horseback as the Persians did.

26 Athenaeus, Deipnosophists, I, 18A. 
4th-century BC Macedonia, the hunt came to take on specific associations with royalty and the court may be, at least in part, due to Philip II's and Alexander the Great's encounters with Persian art, ${ }^{27}$ in which the theme of the king as hunter was prevalent, as well as that of neighboring regions like Thrace, where horsemanship was a sign of nobility. ${ }^{28}$ Briant (1991, p. 246) argues that if the figures in the frieze are indeed Alexander the Great and Philip II, they are shown here "à la macédonienne", in a manner that recalls the Macedonian "cavalier à la lance". If foreign artistic themes did have any influence, they were adopted to local conditions. In short, even though depictions of the king hunting were by no means exclusive to Macedonia (and had been long been used in Egypt and the Near East), in this case the scene has specifically Macedonian character and meaning. Whoever these men are, this is a royal burial with the frieze depicting a group of elite men from the Macedonian court who demonstrate their bravery and elite status by engaging in a hunt. Regardless of the identity of the two men, they embody the quintessential Macedonian male and, more specifically, the quintessential Macedonian king. In that sense, although the figures likely do represent historical individuals, they transcend those identities towards an ideal of masculinity and royalty that was universally recognized in Macedonian society. ${ }^{29}$

The Vergina hunters are frozen in a moment of animated anticipation just before the killing of the lion. The protagonists are thus suspended in time in the instant preceding their heroic action and in this way "small actions appear longlasting and monumental" (Cohen 2010, p. 289). This means of representing the deceased just before the act of killing either an animal or human enemy is also employed on the Alexandrian funerary monuments, in which we see cavalrymen galloping into implied or presumed battle, in the instant just before the real action begins. On the Moustapha Kamel frieze, the riders and women are in the act of reaching forth to pour libations, but the moment of offering has not yet occurred. In terms of technique, the Vergina painting appears to have started al fresco and finished al secco. ${ }^{30}$ A similar combination of these two techniques was used to create the painted frieze at Moustapha Kamel.

A visual expression of the interchangeability of hunt and battle is found in a Thracian tomb near Alexandrovo (Kitov 2009, 2001). The 4th-century BC tomb consists of a corridor, small rectangular antechamber, and circular burial chamber with a domed roof. Each of the three spaces is painted. Much of the extant fresco decoration is too damaged to be legible and, in some cases, it is not preserved. In the corridor are two separate scenes of cavalrymen in combat with enemies on foot-one on the north wall and one on the south (Kitov 2009, p. 28, Figures 23 and 24, p. 30, Figures 25 and 26; Kitov 2001, pp. 18-19, Figures 3 and 4). The scene on the north wall preserves the front part of a rearing horse, ridden by a soldier. The horse's harness is decorated with gold appliques. The rider confronts a foot soldier who holds a round shield in his left hand and a spear in his right. He is nude and shown in a position of retreat, moving to the left as the rider pursues him. The image on the south wall is even more badly damaged - it seems that a horseman is present, again confronting an opponent on foot. He wears a pale tunic with red leggings and raises a spear in his right hand. The foot soldier wears a Phrygian helmet, like the one portrayed in the Kinch tomb and the Kazanlak tomb (discussed below). This type of helmet was adopted by both Macedonians and Thracians. He seems to stand with his back to the viewer, turning his head in profile to the left. In his right hand, the soldier raises a sword and in his left he holds a shield. He wears a short red belted tunic decorated with thick vertical bands of white. A second figure kneels at the foot soldier's back. This individual's gender is difficult to determine, ${ }^{31}$ he or she wears a lightly colored tunic and appears to be unarmed.

27 See e.g., (Palagia 2000).

28 (Franks 2012, pp. 48-52; Cohen 2010, pp. 82-93). Coinage of the Thracian Bisalti dating to ca. 500 BC depict horsemen (Franks 2012, p. 44, Figures 31 and 32) and may even have influenced the adoption of this motif on Macedonian regal coinage. 29 See especially (Franks 2012; Cohen 2010, pp. 237-97).

30 (Saatsoglou-Paliadeli 2006, p. 215; Saatsoglou-Paliadeli 2004, pp. 33-34; Andronicos 1984, p. 113). On materials and techniques, see also (Brecoulaki 2006, pp. 119-29).

31 Kitov (2009, pp. 29-30) believes this is a woman. 
Another combat scene adorns the triangular lintel above the entrance from the antechamber to the circular chamber (Kitov 2009, p. 35, Figure 32; Kitov 2001, pp. 35, 19-21, Figure 5). This painting is better preserved than the previous two. A cavalryman rides his rearing horse to the right. The horse wears a colorful saddle cloth and its neck is hung with pendants. The rider's head is damaged, but he wears a short white tunic with a red belt, red leggings, and pointed shoes. He raises a spear in his right hand, aimed at an opponent who faces him on foot. The foot soldier raises a shield in his right hand; it is unclear whether he held a weapon in his left. His short white tunic is decorated with red vertical bands and a red belt-the garment rises up in the back to expose his buttocks. These three encounters may depict battles between Thracian tribes.

The circular chamber is decorated with a sequence of hunt scenes that are the best-preserved paintings in the tomb. The frieze includes four hunters on horseback, accompanied by dogs and more simply dressed or nude attendants on foot, hunting a stag, a deer, and two boars (Kitov 2009, p. 55, Figure 55, pp. 56-62, Figures 56-65, pp. 64-74, Figures 67-81, p. 77, Figure 83, p. 80, Figure 85, p. 81, Figure 87, pp. 84-86, Figures 89-93; Webber 2003, pp. 534-35, Figure 5; Kitov 2001, pp. 19-29, Figures 6-14). Unlike the Vergina hunt frieze, in which there is a clear emphasis on certain figures but an overall expression of collective, coordinated effort, this frieze shows three distinct groups in sequence, each led by a horseman whose pursuit of his prey forms the primary focus. The combat scenes in the corridor and antechamber also focus on singular encounters between a cavalryman and an enemy on foot. In the hunting sequence, the four horses all rear up and each horseman carries a long spear. The horses are outfitted with colorful saddle cloths and the animals are adorned with ornaments that were probably bronze or silver. ${ }^{32}$ Georgi Kitov (2001, p. 28) has suggested that three of the four horsemen are in fact the same man: the deceased, represented in different hunting scenarios. In this case, the fourth horseman who appears in one of these episodes would be a companion or attendant. Perhaps the cavalrymen in the corridor frescoes are also all depictions of the deceased-unfortunately their faces are too damaged for comparison. Just as in Macedonia, in Hellenistic Thrace one's skill at the hunt was believed to be closely related to one's ability in battle (Andrianou 2017, p. 118). That images of hunt and combat appear together in the same burial places these pursuits on equal footing. ${ }^{33}$

A Macedonian tomb at Lefkadia (Tomb II, also known as the Kinch Tomb) dates to the first half or middle of the 3rd century BC. A painting from the lunette of the tomb's burial chamber, which is now lost but preserved through a watercolor illustration, depicts a warrior on horseback wearing a hybrid Graeco-Persian outfit (Plantzos 2018, pp. 240-41, Figure 225; Miller 2014, pp. 187-88, Figure 5.8; Cohen 2010, pp. 141-43, Figure 68; Brecoulaki 2006, pp. 219-21, pl. 77.2; Moreno 2004, pp. 219-20, Figure 336; Swindler 1929, p. 300, Figure 482; Kinch 1920, pls. I-IV). He gallops to the right, toward a Persian enemy standing before him who raises a shield in defense against the warrior's long spear. ${ }^{34}$ The rider wears the Phrygian helmet together with a Persian tiara. His short-sleeved, belted chiton is colored deep blue and purple-red. Under his chiton he wears a pale yellow long-sleeved garment. His chlamys, also purple-red, flows behind him. His opponent is much less colorfully dressed in white turban-like head covering, pale green chiton, pink leggings, and yellow shield. The Persian elements of the rider's costume and his horse's unusual leopard-skin saddlecloth might be spoils of war, a reference to this soldier's participation in Alexander's eastern campaigns or a more general allusion to the exotic. ${ }^{35}$ His legs were damaged at the time of discovery, but he may also have worn long

32 For Thracian metalwork, including horse trappings, see (Tonkova 2011).

33 Similarly, a sarcophagus found at Çan (early 4th century BC) and the Alexander Sarcophagus from Sidon (late 4th century BC) both juxtapose hunts on horseback with scenes of warfare in which the main protagonists are mounted riders: see (Cohen 2010, pp. 119-27). For scenes of hunters on horseback from Greek-style Phoenician sarcophagi of the 5th-4th century BC, see (Franks 2012, pp. 32-35, Figures 20-25; Palagia 2000, pp. 178-179, Figures 2-7).

34 Moreno (2004, p. 220) interprets the figure on foot as the rider's attendant, but it is apparent that the rider aims his weapon at this man, who raises his shield and bends his knees in a defensive posture. The shield he holds is of a Macedonian type, but Cohen (2010, p. 142) explains this object as having been discarded by a fallen soldier and picked up by the enemy.

35 Palagia (2000, pp. 200-1) asks whether the rider might be Alexander himself. 
leggings. This man is presumably the deceased. Brecoulaki has noted that the posture and expressions of the two soldiers-the heroically brave Macedonian cavalryman charging a frightened and unarmed Persian-is similar to the way in which Alexander the Great and his Persian adversaries are shown on the Alexander Mosaic. ${ }^{36}$ The depiction of a solitary warrior, engaged in direct combat with a single opponent, bears a strong similarity to the Alexandrovo paintings and to the isolated images of cavalrymen on horseback in the Alexandrian funerary monuments (though on those monuments, an enemy is not depicted). Kinch (1920, p. 288) observed that the painting was executed by applying lime paint to a dry coating.

A late 4th-3rd-century BC Thracian tomb at Kazanlak contained the burial of a man and woman (Venedikov 1986; Mikov 1954). The skeleton of a horse was found in the tomb's antechamber (Mikov 1954, pp. 24-25). Other elite Thracian tombs of the 4th century BC contained horse skeletons and/or horse trappings; these are often associated with warriors (Archibald 1998, pp. 247-51). The layout of the tomb is similar to the one at Alexandrovo, but more simplified, with a corridor leading to a single, circular burial chamber. The eastern and western walls of the corridor were decorated with painted friezes of battle scenes. ${ }^{37}$ The scenes include infantrymen and cavalrymen and may show confrontations between Thracians and Macedonians. In both scenes, a mixture of infantry and cavalry approach from right and left toward a pair of soldiers who face off on foot at center. The soldiers wear chitons and some have a chlamys, helmet, or shield. In each scene, only one cavalryman is depicted with a beard, setting him apart from the others. Lyudmila Zvkova suggested that the bearded man is the Odrysian king Seuthes III, ${ }^{38}$ who ruled from about 331-300 BC, in which case the scenes may depict battles in which the king and the deceased man interred in the tomb participated. These scenes, together with the presence of a horse's skeleton within the tomb, emphasize the relationship between horsemanship, battle, and elite status in Thrace. The color palette of these paintings is similar to others from Macedonia and Thrace: blue, brown, red, and yellow. The paintings were executed in fresco technique "sur une base de mortier mélange avec de la poucre de marbre" (Mikov 1954, p. 18).

The Macedonian association between hunting and royalty was adopted by the Ptolemies in Egypt. According to Pliny, ${ }^{39}$ the painter Antiphilus created a painting of Ptolemy I as a hunter. The Ptolemies also followed Alexander in showing themselves as victorious warriors on horseback. On the Raphia Stele, which commemorates Ptolemy IV's victory over Antiochus III in 217 BC, Ptolemy sits astride a rearing horse (Fischer-Bovet 2014, p. 129, Figure 4.3; Hölbl 2000, p. 163, Figure 6.1). He aims his sarissa forward and wears the Egyptian double crown and a kilt, presenting himself in an image that combines attributes of an Egyptian pharaoh and a Macedonian soldier. Arsinoe III stands behind him in the manner and dress of an Egyptian queen. She holds an ankh symbol in her right hand and supports a staff with her left. Her headdress is made up of double plumes and a solar disc. Here, Ptolemy IV combines the traditional pharaonic manner of representation for himself and his queen with the Macedonian motif of a warrior on horseback carrying a long spear as a means by which to appeal to a Graeco-Egyptian audience, merging two separate cultural ideals of kingship into a single image.

\section{Early Alexandria and the Ptolemaic Cavalry}

Having established that this particular type of representation of a cavalryman on horseback has precedents in Macedonia and Thrace, the question arises of its significance in the context of an Alexandrian tomb. Early Alexandria was a multicultural place with a population made up of native

36 (Brecoulaki 2006, p. 220). See also a drawing of a now-lost painting from a late 4th-century BC tomb at Dion in Macedonia that depicts an equestrian battle between Greeks and Persians: (Cohen 2010, pp. 136-37, Figure 63; Brecoulaki 2006, pp. 249-51).

37 (Mikov 1954, pp. 8-10, 15-17, pl. III-V, XXV-XXVI). For digital reconstructions of the paintings, see (Webber 2003, p. 546, Figure 12d, 12e).

38 (Zvkova 1974, p. 18). For details of the possible Seuthes figure, see (Webber 2003, p. 545, Figure 12c).

39 Pliny, Natural History, 35.138. 
Egyptians and immigrants from throughout the eastern Mediterranean. ${ }^{40}$ Among these immigrants, were men who served as mercenaries in the Ptolemaic army, many of whom were of Macedonian, Thracian, and Thessalian origin. Previous scholarship on Ptolemaic Egypt preferred a separatist model in which a strong divide was drawn between "Egyptians" and "Greeks", assuming little to no mingling between these groups, but more recently the focus has shifted towards an understanding that there was indeed a significant degree of cross-cultural exchange even in the early Ptolemaic period, and scholarship is moving beyond a binary understanding of cultural and ethnic identity in this context. ${ }^{41}$ We must also be careful not to directly equate an artistic style that we recognize as "Egyptian" or "Greek" with ethnicity. ${ }^{42}$ Individuals in Ptolemaic Egypt often employed a range of styles and iconography drawn from varied traditions in order to actively shape social identities. ${ }^{43}$ This is evident not only in art, ${ }^{44}$ but also in prosopography, where numerous individuals are attested using so-called double names (one Egyptian and one Greek). ${ }^{45}$

In the case of the monuments listed above, we are fortunate in that three of them provide inscriptions that explicitly give the owner's place of origin and show that he identified with a Macedonian or Thessalian ethnic. Macedonian, Thracian, and Thessalian ethnics are also attested elsewhere in the Ptolemaic sources (La'da 2002). For example, an inscription dated 8 March 267 BC, during the reign of Ptolemy II, lists the names, patronyms, and ethnics of men who won a series of athletic competitions that were probably held during the festival of Basileia (Walker and Higgs 2001, pp. 115-16, cat. 115). Among the 20 preserved names are five Macedonians, eight Thracians, and two Thessalians. These men were most likely cleruchs (soldiers who had been given grants of land by the king) living in the Fayyum district. Though early Ptolemaic soldiers stressed their places of origin, individuals do not appear to have confined themselves socially or in a funerary context to others from the same region. The five funerary monuments listed above come from at least three cemeteries in Alexandria and were therefore not restricted to any one location, family, or burial group. And indeed, necropoleis and even individual tombs could contain burials of Alexandrians from multiple points of origin; cemeteries and tombs were not ethnically segregated (Venit 2002, pp. 43-44). The stela of Pelopides, which was found alongside stelae inscribed for Galatians, is a case in point.

Christelle Fischer-Bovet (2011, p. 152) estimates that about 5\% of the total population in Egypt during the Ptolemaic period was Greek, for a total of 200,000 individuals. In the early Ptolemaic period, prior to the Battle of Raphia in 217 BC, there were about 63,500 Greek adult males who immigrated to Egypt, about 40,000 of whom were soldiers (p. 151). The Ptolemies settled many of these men on land grants in the Egyptian chora (countryside). One-fourth to one-third of Greek military settlers were Macedonian (pp. 142-43). Thracians formed the third largest group of immigrants attested in the chora, after Greeks and Macedonians (La'da 2003, p. 159). Thracians, too, are recorded in the papyrological record as cavalrymen in the service of the Ptolemies. ${ }^{46}$ Of the forces that made up the Ptolemaic army, the cavalrymen formed an elite minority. In the 3rd century BC, the size of the Ptolemaic army is estimated to have been around 30,000-40,000 soldiers (Fischer-Bovet 2014, p. 54).

40 See, e.g., (McKechnie and Cromwell 2018; Fischer-Bovet 2011; Weber 2010; Hinge and Krasilnikoff 2009).

41 For recent summaries of this issue, see (Landvatter 2018, pp. 199-202; Fischer-Bovet 2014, pp. 4-6) with a focus on the Ptolemaic army. See (Lloyd 2002) on Egyptian elites in the early Ptolemaic period.

42 See (Martin 2017), who challenges traditional definitions of "Greek" and "Phoenician", as well as ingrained notions about artistic style as a reflection of ethnicity, in the study of classical art history.

43 See, e.g., (Cole 2019; Versluys 2010; Baines 2004).

44 There is evidence that elite individuals in Ptolemaic Egypt were sometimes depicted in portrait sculptures that showed them in both Greek and Egyptian styles, just as Ptolemaic rulers did (for which see Stanwick 2002). The Callimachos Decree from Thebes orders three statues of the strategos Callimachos, two to be made in hard stone and one in bronze; these materials likely equate to Egyptian and Greek styles, respectively: see Poole in (Spier et al. 2018, pp. 170-71, cat. 102; Burstein 1985, pp. 144-46, no. 111).

45 See most recently (Coussement 2016).

46 (Bingen 2007, pp. 83-93). On Thracians in Ptolemaic Egypt, see also (Goudriaan 1992, pp. 77-79; Velkov and Fol 1977), though I agree with Bingen that Velkov and Fol are incorrect in their conclusion that the Thracians occupied a low social standing under the Ptolemies. 
In the Battle of Gaza in 312 BC, Ptolemy I employed 22,000 infantry and 4000 cavalry. ${ }^{47}$ The size of the Ptolemaic army increased about a century later at the Battle of Raphia through the recruitment of additional Egyptian and Libyan soldiers: Polybius tells us that Ptolemy IV employed 70,000 infantry and 5000 cavalry. ${ }^{48}$ Five men were entrusted with reorganizing the Ptolemaic army in preparation for the battle-three of these five were Thessalians. ${ }^{49}$ Greek immigration to Egypt virtually ended after the 3rd century BC and from that time onward, intermarriage and cross-cultural exchange continued to take place as an increasingly Graeco-Egyptian culture emerged (Fischer-Bovet 2011, p. 144 and n. 37). Consequently, the use of individual ethnics in the papyrological and epigraphic record decreased from the 2nd century BC onward.

While the Ptolemaic army included Egyptian soldiers, Egyptians were not permitted to serve in the cavalry until the second half of the 2 nd century BC. ${ }^{50}$ The funerary monuments above date to the period from the late 4 th-3rd century BC, a time during which the immigrant inhabitants of Alexandria may have particularly wished to assert their identity as both high status and non-Egyptian, and to make references to their homelands. ${ }^{51}$ Because Egyptians did not serve in the cavalry at this time, visually communicating one's status as a cavalryman made a clear statement of non-Egyptianness.

The hunter or warrior on horseback simultaneously signaled a connection to the Macedonian and Thracian elite spheres while also implying associations with the Ptolemaic court. Similar images appear on portable Hellenistic art such as coinage, ${ }^{52}$ painted vases, ${ }^{53}$ terracottas, $^{54}$ mold-made pottery, ${ }^{55}$

47 Diodorus 18.4.3-4.

48 Polybius, Histories, 5.79.2.

49 Polybius, Histories, 5.63.11-12.

0 (Fischer-Bovet 2014, p. 132); on Egyptians in the Ptolemaic army, see (Fischer-Bovet 2014, pp. 161-66).

51 Landvatter (2018) similarly argues that the use of cremation in the burials of the Shatby cemetery was meant as a rejection of Egyptian funerary practices and an assertion of non-Egyptian identity in the early Ptolemaic period.

52 Images of horsemen were in use on Macedonian coinage long before the Hellenistic period: Alexander I (r. 498-454 BC), the first Macedonian king to inscribe his name on his coinage, frequently employed this motif. He was followed by subsequent Macedonian kings: see (Franks 2012, pp. 40-48, Figures 28, 30, 33-40). Alexander the Great appears on his coinage as both a mounted hunter and warrior: see (Wartenberg). The successors of Alexander adopted similar imagery on their coinage-a notable example is Eucratides of the Graeco-Bactrian kingdom (r. 171-145 BC), who appears on the obverse in a Macedonian military helmet, with two mounted riders on the reverse: e.g., (Thonemann 2015, pp. 98-100, Figure 5.19-5.20, p. 150, Figure 8.6).

53 For instance, an amphora found at Kültepe, Cappadocia dating to the 4th-3rd century BC shows a hunter mounted on horseback aiming his spear at a leopard: (Miller 2014, p. 196, Figure 5.16; Özgüç 1971, pp. 92-93, pl. 30). Another noteworthy example-though from an earlier period-that shows a Near Eastern connection is a lekythos by the Xenophantes Painter (ca. 390-380 BC) that shows Persians (including one on horseback and one in a horse-drawn chariot) hunting both real and fantastical animals: (Cohen 2010, pp. 87-88, 89, Figure 33). For examples of warriors with their horses on earlier red-figure Attic vases from the late 6 th-5th centuries BC, roughly contemporaneous with the reign of Alexander I of Macedon, see (Tripodi 1998, pp. 26-28, 144-45, Figures 4-6).

54 Votive terracotta plaques from Hellenistic Troy show mounted warriors and hunters: (Thompson 1963, pp. 108-116, no. 108-128, pl. XXVII-XXVIII). A notable example from Egypt is a terracotta figure of the dwarf god Bes as a mounted warrior in the Greek tradition: (Török 1995, pp. 37-38, no. 19, pl. VII). Bes is shown with his characteristic animal-like face and dwarf-like legs, but has a muscular torso and wears a kilt. In his right hand, Bes raises his sword above his head. In his left, he holds a round shield. The horse moves to the right and rears up. The figure dates to the late 2 nd or early 1 st century $\mathrm{BC}$ and shows that, by this time, artists were experimenting with syncretic mixtures of Egyptian religion and the Greek horseman-hero. Another monument that encapsulates this syncretism is a limestone relief stele found at Tebtunis in the Fayyum, which depicts the god Heron (originally Thracian Heros, this god became popular among Ptolemaic soldiers) astride a horse that rears to the right. He wears a tunic and an Egyptian royal nemes headdress; in his right hand, he holds out a phiale. The stele dates to the 1st century B.C. and is inscribed in both Demotic (illegible) and Greek. The Greek inscription records the name of the dedicator of the stele as Manres, also called Sisois: (Nachtergael 1996).

55 (Rotroff 1982, p. 19, nos. 238-72, pl. 46-54). These were found in Athens but Palagia $(2000,206$ note 170) raises the possibility that they were manufactured in Alexandria. 
faience vessels, ${ }^{56}$ bronze, ${ }^{57}$ silver, ${ }^{58}$ jewelry, ${ }^{59}$ and sandwich gold glass, ${ }^{60}$ all of which may be media through which this motif physically traveled from one geographical area to another. But it was not only the iconography and the technical knowledge of how to execute Greek paintings that crossed cultural and geographical boundaries in the early Hellenistic period, the associated, culturally specific ideas about what defined the ideal elite male, which were embedded in these images, moved along with them.

Andrew Erskine (2013) has argued that the city of Alexandria itself had multiple identities. Depending upon which foundation myth one adhered to, the city could be seen as Greek, Macedonian, or Egyptian. In this way, each Alexandrian found his or her own sense of meaning and belonging. According to Stefan Schmidt (2010), Alexandrian tombs were particularly important as centers for small, exclusive communities to gather and express a collective identity through funerary rituals and ongoing responsibilities of the funerary cult, reflecting the social organization of the city itself. Lacking the communities and social structures that had defined them in their home cities, inhabitants of early Alexandria needed to form new means of social organization and find new ways of signaling group and individual identity. Tombs were crucial spaces in which these negotiations happened. The mercenaries living in Alexandria in the late 4th and early 3rd centuries BC were faced with the task of establishing their place within society and the role(s) they saw themselves as fulfilling. Part of this process involved importing familiar practices from home and further emphasizing those connections through the use of ethnics in inscriptions. Because much of the surviving evidence is funerary, it is difficult to approach how these men established a collective identity in life and whether that identity differed from that which they chose to express in death. We can attempt, however, to address these questions in reverse by looking at their funerary art and, as Schmidt suggests, seeing in it an expression of the living communities in Alexandria.

Perhaps the portable nature by which images of warriors and hunters on horseback may have reached Alexandria encouraged its use on smaller-scale funerary monuments rather than as large-scale painted friezes. The painted stelae can be seen as a confluence of Greek painting, northern Greek relief stelae of horsemen, and frescoed friezes from monumental northern Greek tombs depicting hunts and battles on horseback. Imported into early Ptolemaic Alexandria, the intention behind such images remained essentially the same: to present the deceased as the ideal elite male. In the Macedonian sense, as a victorious mounted warrior. The painted Alexandrian funerary monuments carried the same socio-cultural significance as their northern Greek counterparts but, in the context of Alexandria they took on the added significance of declaring non-Egyptian identity and asserting a connection to one's homeland. The monuments demonstrate that northern Greek mercenaries in the Ptolemaic army brought with them not only iconography, techniques, and styles of art but also systems of value.

Funding: This research received no external funding.

Acknowledgments: I would like to thank Kyriakos Savvopoulos, Marie-Dominique Nenna, Marjorie S. Venit, and Branko van Oppen for generously providing images.

Conflicts of Interest: The author declares no conflict of interest.

\section{Abbreviation}

LIMC Lexicon iconographicum mythologiae classicae

56 (Nenna and el-Din 2000, pp. 86-88, 281 no. 369, pl. 56): a fragmentary Egyptian faience vase shows a nude warrior on horseback spearing his fallen enemy.

57 A bronze mirror cover shows two nude youths hunting a boar: (Cohen 2010, p. 73, Figure 25; Schwarzmaier 1997, p. 266, no. 78; Comstock and Vermeule 1971, p. 255, no. 367).

58 Silver appliques from the 4th-century BC Letnitsa treasure in Thrace: (Martinez et al. 2015, pp. 344-46, cats. 290-98).

59 A Thracian gold signet ring found near Starosel bears the image of a hunter on horseback attacking a boar: (Kitov 2009 , p. 64 Figure 66; Kitov 2001, p. 25 Figure 15).

60 A gold-glass bowl found in a tomb in Tresilico (Reggio Calabra) depicts a hunter in Greek dress astride a rearing horse. The hunter aims his spear at a leopard. See (Cesarin 2016) for a comparison of this bowl with the hunt-frieze from Vergina Tomb II and a suggestion that the bowl may have been manufactured in Alexandria. 


\section{References}

Abbe, Mark B. 2007. Painted Funerary Monuments from Hellenistic Alexandria. In Heilbrunn Timeline of Art History. New York: The Metropolitan Museum of Art, Available online: http://www.metmuseum.org/toah/ hd/pfmh/hd_pfmh.htm (accessed on 12 March 2019).

Adriani, Achille. 1936. Le Nécropole de Moustafa Pacha (Annuaire 2 [1933/34-1934/35]). Alexandria: Whitehead Morris.

Adriani, Achille. 1952. Annuaire du Musée gréco-romaine III (1940-1950). Alexandria: Whitehead Morris Limited. Andrianou, Dimitra. 2017. Memories in Stone: Figures Grave Reliefs from Aegean Thrace. Athens: Ethniko Hidryma Ereunōn, Institouto Historikōn Ereunōn.

Andronicos, Manolis. 1984. Vergina. The Royal Tombs and the Ancient City. Athens: Ekdotike Athenon S.A.

Archibald, Z. H. 1998. The Odyrisan Kingdom of Thrace. Oxford: Clarendon Press.

Arvanitopoulos, A. S. 1928. Graptai stēlai Dēmētriados-Pagason. Athens: P.D. Sakellarios.

Badian, Ernst. 1999. A Note on the 'Alexander Mosaic'. In The Eye Expanded: Life and Arts in Greco-Roman Antiquity. Edited by F. B. Titchener and R. F. Moorton Jr. Berkeley and Los Angeles: University of California Press, pp. 75-92.

Baines, John. 2004. Egyptian Elite Self-Presentation in the Context of Ptolemaic Rule. In Ancient Alexandria between Egypt and Greece. Edited by W. V. Harris and Giovanni Ruffini. Leiden and Boston: Brill, pp. 33-61.

Baumer, Lorenz, and Ursula Weber. 1991. Zum Fries des 'Philippgrabes' von Vergina. Hefte des Archäologischen Seminars der Universität Bern 14: 27-41.

Bingen, Jean. 2007. Hellenistic Egypt: Monarchy, Society, Economy, Culture. Berkeley: University of California Press. Boteva, Dilyana. 2011. The 'Thracian Horseman' Reconsidered. In Early Roman Thrace: New Evidence from Bulgaria. Journal of Roman Archaeology Supplementary Series Number Eighty-Two. Edited by Ian P. Haynes. Portsmouth: Journal of Roman Archaeology, pp. 85-106.

Breccia, Evaristo. 1905. La Necropoli di Sciatbi. Bulletin de la Société royale d'archéologie d'Alexandrie 8: 55-100.

Breccia, Evaristo. 1912. La Necropoli di Sciabti. Cairo: Institut français d'archéologie orientale.

Breccia, Evaristo. 1930. Nuovi scavi nelle Necropoli di Hadra. Bulletin de la Société archéologique d'Alexandrie 25: 99-132.

Brecoulaki, Hariclia. 2006. La Peinture Funéraire de Macédoine: Emplois et Fonctions de la Couleur IVe-IIe s. av. J.-C. Athens: Centre de Recherches de l'antiquité Grecque et Romaine, Fondation Nationale de la Recherche Scientifique.

Briant, Pierre. 1991. Chasses royales macédoinnes et chasses royales perses: le theme de la chasse au lion sur la chasse de Vergina. Dialogues d'histoire ancienne 17: 211-55. [CrossRef]

Brown, Blanche R. 1957. Ptolemaic Paintings and Mosaics and the Alexandrian Style. Cambridge: Archaeological Institute of America.

Burstein, Stanley M. 1985. The Hellenistic Age from the Battle of Ipsos to the Death of Kleopatra VII. Cambridge and New York: Cambridge University Press.

Casagrande-Kim, Roberta, ed. 2014. When the Greeks Ruled Egypt: from Alexander the Great to Cleopatra. New York: Institute for the Study o the Ancient World, Princeton: Distributed by Princeton University Press.

Cesarin, Giulia. 2016. Hunters on Horseback: New Version of the Macedonian Iconography in Ptolemaic Egypt. In Alexander the Great and the East: History, Art, Tradition. Edited by Krzystof Nawotka and Agnieszka Wojciechowska. Wiesbaden: Harrassowitz Verlag, pp. 41-50.

Cohen, Ada. 2010. Art in the Era of Alexander the Great: Paradigms of Manhood and their Cultural Traditions. Cambridge: Cambridge University Press.

Cole, Sara E. 2019. Cultural Manoeuvring in the Elite Tombs of Ptolemaic Egypt. In The Ancient Art of Transformation: Case Studies from Mediterranean Contexts. Edited by Renee M. Gondek and Carrie L. Sulosky Weaver. Oxford: Oxbow Books, pp. 76-106.

Comstock, Mary, and C. Vermeule. 1971. Greek, Etruscan and Roman Bronzes in the Museum of Fine Arts, Boston. Greenwich: New York Graphic Society.

Cook, Brian. 1966. Inscribed Hadra Vases in the Metropolitan Museum of Art. Papers of the Metropolitan Museum of Art. New York: The Metropolitan Museum of Art, vol. 12.

Coussement, Sandra. 2016. 'Because I Am Greek': Polyonymy as an Expression of Ethnicity in Ptolemaic Egypt. Leuven: Peeters. 
Dimitrova, Nora. 2002. Inscriptions and Iconography in the Monuments of the Thracian Rider. Hesperia: The Journal of the American School of Classical Studies at Athens 71: 209-29. [CrossRef]

Empereur, J. Y., and M. D. Nenna, eds. 2001. Nécropolis 1. Cairo: IFAO.

Empereur, J. Y., and M. D. Nenna, eds. 2003. Nécropolis 2. 2 vols. Cairo: IFAO.

Erskine, Andrew. 2013. Founding Alexandria in the Alexandrian Imagination. In Belonging and Isolation in the Hellenistic World. Edited by Sheila L. Ager and Riemer A. Faber. Toronto, Buffalo and London: University of Toronto Press, pp. 169-83.

Fabricius, Johanna. 1999. Die Hellenistischen Totenmahlreliefs: Grabrepräsentation und Wertvorstellungen in Ostgriechischen Städten. Munich: F. Pfeil.

Fischer-Bovet, Christelle. 2011. Counting the Greeks in Egypt: Immigration in the first century of Ptolemaic rule. In Demography and the Graeco-Roman World: New Insights and Approaches. Edited by Claire Holleran and April Pudsey. Cambridge: Cambridge University Press, pp. 135-54.

Fischer-Bovet, Christelle. 2014. Army and Society in Ptolemaic Egypt. Cambridge: Cambridge University Press.

Franks, Hallie M. 2012. Hunters, Heroes, Kings: The Frieze of Tomb II at Vergina. Princeton: American School of Classical Studies at Athens.

Fraser, P. M. 1977. Rhodian Funerary Monuments. Oxford: Clarendon Press.

Fredricksmeyer, E. A. 1986. Alexander the Great and the Macedonian Kausia. Transactions of the American Philological Association (1974-2014) 116: 215-27. [CrossRef]

Goudriaan, Koen. 1992. Ethnical Strategies in Graeco-Roman Egypt. In Ethnicity in Hellenistic Egypt. Edited by Per Bilde, Troels Engberg-Pedersen, Lise Hannestad and Jan Zahle. Aarhus: Aarhus University Press, pp. 74-99.

Hassan, Fekri, ed. 2002. Alexandria Graeco-Roman Museum: A Thematic Guide. Egypt: National Center for Documentation of Cultural and Natural Heritage and the Supreme Council of Antiquities.

Hatzopoulos, Miltiades B. 2016. The Burial of the Dead (at Vergina) or the Unending Controversy on the Identity of the Occupants of Tomb II. Tekmeria 9: 91-118. [CrossRef]

Hatzopoulos, Miltiades B., and Pierre Juhel. 2009. Four Hellenistic Funerary Stelae from Gephyra, Macedonia. American Journal of Archaeology 113: 423-37. [CrossRef]

Hinge, George, and Jens A. Krasilnikoff, eds. 2009. Alexandria: A Cultural and Religious Melting Pot. Aarhus: Aarhus University Press.

Hölbl, G. 2000. History of the Ptolemaic Empire. Translated by T. Saavedra. London and New York: Routledge.

Hughes, Dennis D. 1999. Hero Cult, Heroic Honors, Heroic Dead: Some Developments in the Hellenistic and Roman Periods. In Ancient Greek Hero Cult: Proceedings of the Fifth International Seminar on Ancient Greek Cult, Organized by the Department of Classical Archaeology and Ancient History, Göteborg University, 21-23 April 1995. Edited by Robin Hägg. Stockholm: Svenska Institutet i Athen, Jonsered: Distributor P. Åström, pp. 167-75.

Kalaitzi, Myrina. 2016. Figured Tombstones from Macedonia, Fifth-First Century BC. Oxford: Oxford University Press.

Kinch, Karl Frederik. 1920. Le tombeau de Niausta. Tombeau Macédonien. Mémoires de l'Académie Royale des Sciences et des Lettres de Danemark, Copenhague, 7me Série, Section des Lettres 4: 283-88.

Kitov, Georgi. 2001. A Newly Found Thracian Tomb with Frescoes. Archaeologia Bulgarica 5: 15-29.

Kitov, Georgi. 2009. Alexandrovskata Grobnitsa. Varna.

La'da, Csaba A. 2002. Foreign Ethnics in Hellenistic Egypt. Leuven and Dudley: Peeters.

La'da, Csaba A. 2003. Encounters with Ancient Egypt: The Hellenistic Greek Experience. In Ancient Perspectives on Egypt. Edited by Roger Matthews and Cornelia Roemer. London: UCL, pp. 157-69.

Landvatter, Thomas. 2018. Identity and Cross-cultural Interaction in Early Ptolemaic Alexandria: Cremation in Context. In Ptolemy I and the Transformation of Egypt, 404-282 BCE. Edited by Paul McKechnie and Jennifer A. Cromwell. Leiden and Boston: Brill, pp. 199-234.

Launey, Marcel. 1949-1950. Recherches sur les Armées Hellénistiques. Paris: E. de Boccard.

Lloyd, Alan B. 2002. The Egyptian Elite in the Early Ptolemaic Period: Some Hieroglyphic Evidence. In The Hellenistic World: New Perspectives. Edited by Daniel Ogden. London: The Classical Press of Wales and Duckworth, pp. 117-36.

Martin, S. Rebecca. 2017. The Art of Contact: Comparative Approaches to Greek and Phoenician Art. Philadelphia: University of Pennsylvania Press. 
Martinez, Jean-Luc, Alexandre Baralis, Néguine Mathieux, Totko Stoyanov, and Milena Tonkova, eds. 2015. L'épopée des rois Thraces: Des Guerres Médiques aux Invasions Celtes, 479-278 av. J.-C.: Découvertes Archéologiques en Bulgarie. Paris: Musée du Louvre.

McKechnie, Paul, and Jennifer A. Cromwell, eds. 2018. Ptolemy I and the Transformation of Egypt, 404-282 BCE. Leiden and Boston: Brill.

McKenzie, Judith. 2007. The Architecture of Alexandria and Egypt 300 BC-AD 700. New Haven and London: Yale University Press.

Merriam, Augustus C. 1885. Inscribed Sepulchral Vases from Alexandria. American Journal of Archaeology and of the History of the Fine Arts 1: 18-33. [CrossRef]

Merriam, Augustus C. 1887. Painted Sepulchral Stelai from Alexandria. American Journal of Archaeology and of the History of the Fine Arts 3: 261-68. [CrossRef]

Mikov, Vasil. 1954. Le Tombeau Antique près de Kazanlăk. Sofia: Académie Bulgare des Sciences.

Miller, Stella G. 1993. The Tomb of Lyson and Kallikles: A Painted Macedonian Tomb. Mainz am Rhein: Philipp von Zabern.

Miller, Stella G. 2014. Hellenistic Painting in the Eastern Mediterranean, Mid-Fourth to Mid-First Century BC. In The Cambridge History of Painting in the Classical World. Edited by J. J. Pollitt. Cambridge: Cambridge University Press, pp. 170-237.

Moreno, Paolo. 2004. Alessandro Magno. Immagini Come Storia. Rome: Istituto poligrafico e Zecca dello Stato, Libreria dello Stato.

Nachtergael, Georges. 1996. Trois dédicaces au dieu Hèrôn. Chronique d'Égypte 71: 129-42. [CrossRef]

Nenna, Marie-Dominique, and Merwatte Seif el-Din. 2000. La vaiselle en Fä̈ebce d'époque gréco-Romain. Catalogue du Musée gréco-Romain d'Alexandrie. Cairo: IFAO.

Néroutsos-Bey, Dr. 1887. Inscriptions grecques et latines recueillies dans la ville d'Alexandrie et aux environs. Revue Archéologique 9: 291-98.

Özgüç, Tahsin. 1971. Kültepe and Its Vicinity in the Iron Age. Ankara: Türk Tarih Kunumu Basimevi.

Pagenstecher, Rudolf. 1919. Nekropolis: Untersuchungen über Gestalt und Entwicklung der alexandrinischen Grabanlagen und ihrer Malereien. Leipzig: Giesecke \& Devrient.

Palagia, Olga. 2000. Hephaestion's Pyre and the Royal Hunt of Alexander. In Alexander the Great in Fact and Fiction. Edited by A. B. Bosworth and E. J. Baynham. Oxford and New York: Oxford University Press, pp. 167-206.

Pfuhl, Ernst, and Hans Möbius. 1977-1979. Die ostgriechischen Grabreliefs. Mainz am Rhein: Von Zabern.

Picón, Carlos A. 2007. Art of the Classical World in the Metropolitan Museum of Art: Greece, Cyprus, Etruria, Rome. New York: The Metropolitan Museum of Art.

Plantzos, Dimitris. 2018. The Art of Painting in Ancient Greece. Atlanta: Lockwood Press.

Posamentir, Richard. 2011. The Polychrome Grave Stelai from the Early Hellenistic Necropolis. Austin: University of Texas Press.

Reinach, S. 1888. Review of Neroutsos. L'Ancienne Alexandrie. Revue critique d'histoire et de littérature 26: 420.

Reinach, Adolphe. 1911. Les Galates dans l'art alexandrine. Monuments et mémoires de la Fondation Eugène Piot 18: 37-116. [CrossRef]

Richter, Gisela M. A. 1927. Handbook of the Classical Collection. New York: The Metropolitan Museum of Art.

Richter, Gisela M. A. 1953. Handbook of the Greek Collection. Cambridge: Harvard University Press.

Rostovtzeff, M. I. 1941. The Social and Economic History of the Hellenistic World. Oxford: Clarendon Press.

Rotroff, Susan I. 1982. Hellenistic Pottery: Athenian and Imported Moldmade Bowls. Princeton: American School of Classical Studies at Athens.

Rouveret, Agnès. 2004. Peintures Grecques Antiques: La Collection Hellénistique du Musée du Louvre. Paris: Librairie Arthème Fayard and Musée du Louvre.

Saatsoglou-Paliadeli, Chryssoula. 1993. Aspects of Ancient Macedonian Costume. The Journal of Hellenic Studies 113: 122-47. [CrossRef]

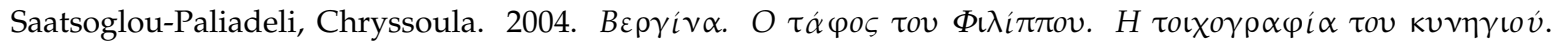
Athens.

Saatsoglou-Paliadeli, Chryssoula. 2006. Reflections on the Painting Technique on Philip's Tomb at Vergina. In Maiandros. Festschrift für Volkmar von Graeve. Edited by R. Biering, V. Brinkmann, U. Schlotzhauer and B. F. Weber. Munich: Biering \& Brinkmann, pp. 213-20. 
Schmidt, Stefan. 2010. Nekropolis-Grabarchitektur und Gesellschaft im hellenistischen Alexandreia. In Alexandreia und das Ptolemäische Ägypten: Kulturbegegnungen in Hellenisticher Zeit. Edited by Gregor Weber. Berlin: Verlag Antike, pp. 136-55.

Schmitt, P., and Alain Schnapp. 1982. Image et société en Grèce ancienne: les representations de la chasse et du banquet. Revue Archéologique, Nouvelle Série 1: 57-74.

Schwarzmaier, Agnes. 1997. Griechische Klappspiegel: Untersuchungen zu Typologie und Stil. Berlin: W. de Gruyter. Spier, Jeffrey, Timothy Potts, and Sara E. Cole, eds. 2018. Beyond the Nile: Egypt and the Classical World. Los Angeles: J. Paul Getty Museum.

Stanwick, Paul Edmund. 2002. Portraits of the Ptolemies: Greek Kings as Egyptian Pharaohs. Austin: University of Texas Press.

Swindler, Mary Hamilton. 1929. Ancient Painting, from the Earliest Times to the Period of Christian Art. New Haven and London: Yale University Press.

Thompson, Dorothy Burr. 1963. The Terracotta Figurines of the Hellenistic Period. Princeton: Published for the University of Cincinnati by Princeton University Press.

Thonemann, Peter. 2015. The Hellenistic World: Using Coins as Sources. Cambridge: Cambridge University Press. Tonkova, Milena. 2011. Les parures d'harnachement en or de Thrace et l'orfevrerie de la haute époque hellénistique. Bolletino di Archeologia on line (Numero special dedicato al Congresso di archeologia, A.I.A.C., 2008), 44-63.

Török, László. 1995. Hellenistic and Roman Terracottas from Egypt. Rome: L’Erma di Bretschneider.

Tripodi, Bruno. 1998. Cacce reali macedoni. Tra Alessandro I e Filippo V. Messina: Di.Sc.A.M.

Velkov, Velizar, and Alexandre Fol. 1977. Les Thraces en égypte Gréco-Romaine. Sofia: Academia Litterarum Bulgarica, Institutum Thracicum.

Venedikov, I. 1986. Koj e pogreban v Kazanlskata grobnitsa. Izkustvo 8: 2-8.

Venit, Marjorie Susan. 2002. The Monumental Tombs of Ancient Alexandria: The Theater of the Dead. Cambridge and New York: Cambridge University Press.

Venit, Marjorie Susan. 2009. Theatrical Fiction and Visual Bilingualism in the Monumental Tombs of Ptolemaic Alexandria. In Alexandria: A Cultural and Religious Melting Pot. Edited by George Hinge and Jens A. Krasilnikoff. Aarhus: Aarhus University Press, pp. 42-65.

Venit, Marjorie Susan. 2016. Visualizing the Afterlife in the Tombs of Graeco-Roman Egypt. New York: Cambridge University Press.

Vermeule, Emily. 1979. Aspects of Death in Early Greek Art and Poetry. Berkeley and London: University of California Press.

Versluys, Miguel John. 2010. Understanding Egypt in Egypt and Beyond. In Isis on the Nile. Egyptian Gods in Hellenistic and Roman Egypt. Edited by Laurent Bricault and Miguel John Versluys. Leiden and Boston: Brill, pp. 7-36.

Walker, Susan, and Peter Higgs, eds. 2001. Cleopatra of Egypt: From History to Myth. Princeton: Princeton University Press.

Wartenberg, Ute. Forthcoming. Early Portraits of Alexander the Great: The Numismatic Evidence.

Webber, Christopher. 2003. Odrysian Cavalry Arms, Equipment, and Tactics. In Early Symbolic Systems for Communication in Southeast Europe. Edited by Lolita Nikolova. Oxford: Archaeopress, pp. 529-54.

Weber, Gregor, ed. 2010. Alexandria und das Ptolemäische Ägypten: Kulturbegegnungen in Hellenistischer Zeit. Berlin: Verlag Antike.

Westgate, Ruth. 2011. Party Animals: The Imagery of Status, Power and Masculinity in Greek Mosaics. In Sociable Man: Essays on Ancient Greek Social Behaviour in Honour of Nick Fisher. Edited by S. D. Lambert. Swansea: Classical Press of Wales, pp. 291-322.

Wypustek, Andrzej. 2013. Images of Eternal Beauty in Funerary Verse Inscriptions of the Hellenistic and Greco-Roman Periods. Leiden: Brill.

Zvkova, Lyudmila. 1974. Kazanlskata grobnitsa. Sofia.

(C) 2019 by the author. Licensee MDPI, Basel, Switzerland. This article is an open access article distributed under the terms and conditions of the Creative Commons Attribution (CC BY) license (http://creativecommons.org/licenses/by/4.0/). 